\title{
How Would the Magyar Nemzeti Bank's Liquidity and Funding Requirements Have Influenced the Impact of the 2008 Crisis in Hungary?*
}

\author{
Tamás Borkó - Evelyn Herbert - Barnabás Székely - Péter Szomorjai
}

Building on the experiences from the financial crisis, after 2012 the Magyar Nemzeti Bank (MNB, the Central Bank of Hungary) introduced various regulations managing liquidity and funding risks that affected the whole banking system, disincentivising the emergence of business practices jeopardising short- and long-term solvency. The instruments addressing currency mismatches, for example the Foreign Exchange Funding Adequacy Ratio, the Foreign Exchange Coverage Ratio, the Interbank Funding Ratio as well as the Liquidity Coverage Ratio introduced at the EU level reduce the probability of system-wide liquidity and funding shocks in Hungary and may keep the Hungarian banking system's short-term external vulnerability permanently low. By backtesting the impact of the above-mentioned regulations, this analysis confirms that these instruments would have been effective in curbing the emergence of the banking system vulnerabilities observed prior to the 2008 crisis. It can also be argued that, by internalising the costs of the riskier funding practices in the banking system, they would have been able to slow the pace of the build-up of the FX loans that later led to devastating effects in the national economy and society, and to mitigate the risks related to excessive lending.

Journal of Economic Literature (JEL) codes: E58, G01, G21

Keywords: financial stability, liquidity, funding, macroprudential policy, short-term external debt, FX lending

\section{Introduction}

The 2007 crisis spread quickly from the credit market to other financial markets of the US, ${ }^{1}$ and all over the globalised financial market. It underlined the significance

\footnotetext{
* The papers in this issue contain the views of the authors which are not necessarily the same as the official views of the Magyar Nemzeti Bank.

Tamás Borkó is a Senior Economic Analyst at the Magyar Nemzeti Bank. Email: borkot@mnb.hu Evelyn Herbert is an Analyst at the Magyar Nemzeti Bank. Email: herberte@mnb.hu Barnabás Székely is an Analyst at the Magyar Nemzeti Bank. Email: szekelyb@mnb.hu Péter Szomorjai is a Senior Supervisor at the Magyar Nemzeti Bank. Email: szomorjaip@mnb.hu
}

The authors wish to thank Gabriella Grosz and Laura Komlóssy for their help in the preparation of the study as well as János Szakács for his valuable comments. Any remaining mistakes are the sole responsibility of the authors.

The Hungarian manuscript was received on 15 June 2020.

DOI: http://doi.org/10.33893/FER.19.4.2759

${ }^{1}$ For the detailed reasons and consequences of the US subprime mortgage crisis, see: Dell'Ariccia et al. (2012) and Demyanyk-Hemert (2011). 
of liquidity in the appropriate operation of financial markets and the banking sector. Cheap funding used to be readily available in the context of active asset markets, however, the quick realignment on the markets showed how rapidly liquidity can evaporate. The banking system experienced extreme stress, which required central banks to act and support financial markets and, in some cases, individual institutions (BCBS 2013).

The magnitude of the economic costs incurred in the financial crisis demonstrated the crucial importance of the stability of the financial system and the low vulnerability of the economy in a country's resilience to shocks. It also underscored that in themselves the so-called microprudential interventions, which ensure the stability and the prudent operation of individual banks, are unable to prevent financial malfunctions that inflict heavy losses on the real economy, and it became clear that systemic macroprudential interventions to manage financial system risks were also necessary. Besides actively curbing systemic financial risks, financial players' individual resilience to risks also had to be effectively improved.

An international response was triggered to manage the shortcomings in liquidity management: the Basel Committee on Banking Supervision prepared two standards, one on liquidity and another one on funding (BCBS 2013; BCBS 2014), in accordance with which the Liquidity Coverage Ratio (LCR) was introduced across the EU in 2015, and the Net Stable Funding Ratio (NSFR) will take effect in 2021. However, these are not always able to manage all the risks that arise at the national level, therefore national liquidity and funding regulations complementing the EU requirements may also be necessary.

The 2008 crisis had a major, albeit indirect effect on the Hungarian banking system. The country's financial vulnerability back then was mainly attributable to household FX lending and the liquidity and solvency risks arising from the related FX funding need. Building on the Hungarian experiences from the financial crisis and taking into account the features of the Hungarian financial system, the MNB introduced various regulations managing liquidity and funding risks that disincentivised the emergence of business practices jeopardising short- and long-term solvency, even before the Basel ratios took effect. At the bottom of the financial cycle, in the context of a practically marginal adjustment requirement, the Deposit Coverage Ratio (DCR) and the Balance Sheet Coverage Ratio (BCR) targeting short-term liquidity risks and functioning as simple LCR indicators were introduced ${ }^{2}$, together with the Foreign Exchange Funding Adequacy Ratio (FFAR), the Foreign Exchange Coverage Ratio (FECR) and the Interbank Funding Ratio (IFR) addressing funding risks, and the Mortgage Funding Adequacy Ratio (MFAR) ensuring forint maturity matching. Coupled with the above-mentioned LCR, these requirements function

\footnotetext{
${ }^{2}$ When the LCR took effect, the two indicators were removed from the MNB's instruments.
} 
as preventive instruments that are able to reduce the probability of system-wide liquidity and funding shocks in Hungary and may keep the Hungarian banking system's short-term external vulnerability permanently low.

Based on the experiences since the crisis, and being especially important in view of the financial and economic shocks emerging in the wake of the coronavirus pandemic, the question arises of what approximate effects the introduction of such rules might have. Therefore a thought experiment is conducted utilising the experiences from the global financial crisis, examining the extent by which the implementation of these rules prior to the crisis would have reduced the vulnerability of the financial system and thus also the economy as a whole. Accordingly, the study aims, on the one hand, to assess the impact of the rules had they been implemented before the 2007-2008 crisis, and on the other hand, to ascertain how this framework can prevent the build-up and materialisation of vulnerabilities in the future, because the lessons learnt also provide information about this.

The backtesting calculation performed in this way suggests that the regulatory framework under review would have significantly reduced short-term interbank external debt. With an asset-side adjustment, the volume of FX loans should have contracted considerably as well, or it would have been unable to build up in the first place, due to the regulatory constraints. It has to be noted, however, that several strong assumptions needed to be made to perform the calculations here; so even though the authors are convinced that the findings are a good approximation for the system as a whole, this analysis merely paints a rough picture about the effects of the regulatory framework.

The second chapter of the study comprises a review of the theoretical and empirical literature on the importance of liquidity and funding regulations. The third chapter presents the features of the Hungarian banking system in the financial crisis that started in 2007-2008, as well as the liquidity and funding regulatory instruments implemented after the crisis. The fourth chapter details the research conducted, while the fifth lists the findings. Finally, the study ends with a summary.

\section{Liquidity and funding risks}

\subsection{Liquidity and funding risks in general}

Credit institutions typically perform maturity transformation during financial intermediation, offering long-term loans against their short-term liabilities. Hence they allow borrowers to smooth their consumption and investment cycles, which increases social welfare but also poses a liquidity risk to credit institutions. 
Traditionally, liquidity has been defined as the credit institution's ability to fund increases in assets and meet obligations as they fall due (BCBS 2000). According to literature, banks' liquidity risks have two distinct but related dimensions: funding risk (creditworthiness on the market) and market liquidity risk (ability to sell or unwind asset positions) (ECB 2002). The former is the risk that credit institutions are unable to meet their payment obligations, or only at the expense of a massive reduction in profitability. Funding risks may arise, for example, due to an unexpected drop in the liquidity available to banks on account of individual problems or a liquidity shortage on the money market, or a sudden surge in liquidity demand triggered by an unanticipated withdrawal of funds or credit line drawdowns. Funding risk is heightened if banks' liabilities include a low amount of customer deposits that are considered so-called core liabilities, making banks rely heavily on other, less stable forms of funding. Market liquidity risk means that credit institutions may only be able to sell their financial assets with a major price loss due to financial market turbulences, turning otherwise liquid assets into illiquid ones (Balás - Móré 2007; Sharma 2004). Funding and market liquidity risks are closely related and may influence each other (Acharya-Schaefer 2005; Brunnermeier - Pedersen 2007). This mutual dependence may deal a heavy blow to financial markets under unfavourable circumstances, since the disturbances on a few segments can easily spill over to others, which may undermine the liquidity of the entire market.

The interaction between market and funding liquidity risks was illustrated by the subprime mortgage crisis in the US that began in 2007. As investor confidence was dented, the market for collateralised debt obligations (CDOs) became increasingly illiquid, and the trapped investors had no choice but to unwind other positions, which made the liquidity stress spread quickly to other markets as well. Parallel to the unwinding of the positions, the reduction of funding liquidity and deleveraging began. Since banks were not only funders but also active investors on the market, they were forced to do multiple rounds of write-downs. The lack of transparency and the uncertainty also had a negative effect on the interbank market, the funding market based on the confidence among banks; this led to an unprecedented jump in interbank rates, and to the interbank market grinding to a halt (Balás - Móré 2007; Nagy - Szabó 2008; Hungarian Financial Supervisory Authority (HFSA) 2013) (Figure 1). 


\section{Figure 1}

Difference between 3-month interbank rate and $\mathrm{O} / \mathrm{N}$ index swap (upper panel), and development of interbank funds (lower panel) prior to and after the 2008 crisis
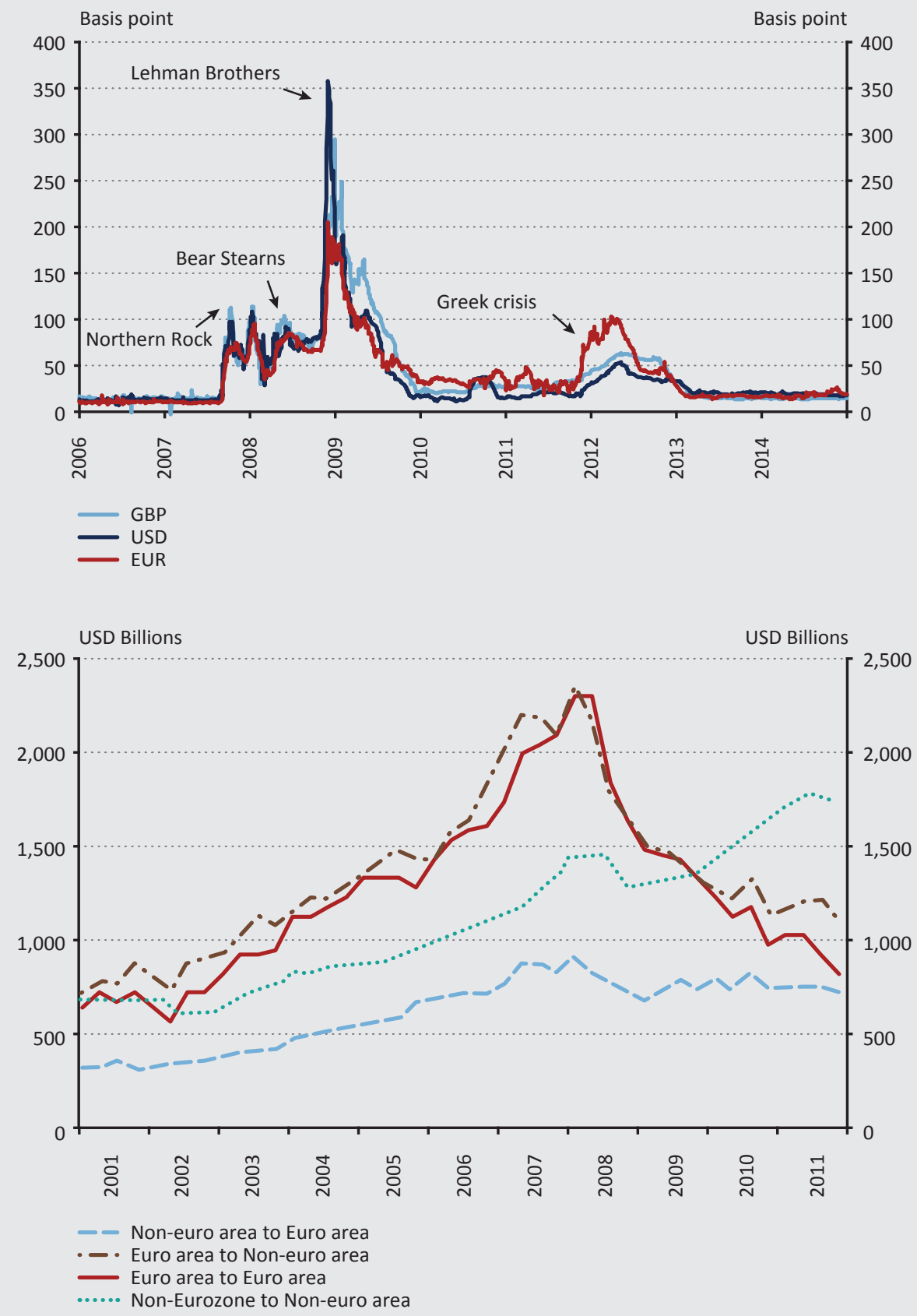

Source: Bloomberg, BIS International banking statistics 
The crisis showed how important the funding structure is in banks' resilience to shocks. As interbank rates soared and the interbank market dried up, banks with an over-reliance on interbank funds were affected by the crisis much more severely. It has been empirically proven for Canada, the UK and the EU countries that the banks that financed their operations to a lesser extent from customer deposits and to a greater extent from interbank funds were clearly more vulnerable during the crisis (Poghosyan - Čihák 2009; Ratnovski - Huang 2009; Yorulmazer - GoldsmithPinkham 2010). The banking business model built on an extensive credit expansion financed to a large degree from foreign and FX funds also caused serious problems in certain countries as the crisis progressed. This practice led to a banking crisis in Iceland, where banks first experienced a major tightening of the funds available from international markets, then foreign depositors also started to withdraw their money, leading to a collapse of all three major banks in Iceland (Baudino et al. 2020).

\subsection{Key risks in funding}

\subsubsection{FX lending}

The expansion in FX lending may pose a risk to financial stability in several ways. In the cases where domestic borrowers without a foreign currency hedge have FX debt, the depreciation of the local currency translates into an increase in the outstanding debt, leading to a deterioration in the debt-servicing capacity of the borrowers. Since the depreciation of the local currency's exchange rate has an adverse effect on a large portion of the private sector holding foreign loans at the same time, a major exchange rate depreciation may generate a systemic financial stability risk for the entire economy (ECB 2010). Moreover, borrowers' default risk may be further compounded if the appreciation of the foreign currency is coupled with a rise in foreign interest rates, especially when floating-rate loans make up a large share of outstanding borrowing (BCBS 2009; Hartmann 2010).

Any significant deterioration in the quality of the FX loan portfolio could expose banks to substantial profitability risk via the significant decrease of interest income along with the growing write-downs and provisions of banks. Furthermore, the souring of the FX loan portfolio may also entail a funding risk for banks. Their funds reserved for the repayment of their own liabilities may be drastically reduced as a result of the slump or disruptions in loan repayments. Therefore, banks find it increasingly hard to repay their maturing liabilities. This increases their demand for funds and their need to roll over debt, which may be impeded by the damaged confidence of their financers on account of the losses related to the FX loan portfolio. Additional funding risk may emerge if banks finance FX lending from funds in different currencies, covering the currency mismatch with FX swaps. In such a scenario, if liquidity plunges on the FX swap market and banks have no 
access to the central bank's instruments providing FX liquidity, a funding risk for FX loans emerges even in the short run (ECB 2010). Any potential exchange rate depreciation entails further risks, since then the losses on the swaps are incurred immediately, while the higher inflows from the increased forint-denominated repayment instalments of FX loans take longer to be collected.

\subsubsection{Short-term external debt}

If external funds dominate an economy's financing structure, that may significantly increase a country's vulnerability. Economies with a scarcity of capital naturally have a need to borrow foreign funds, especially if they are available under better conditions than the domestic funds denominated in the local currency. In times of market turbulences, the greatest drawback of the dependence on external funding is rollover risk, since in crises, foreign funds may become considerably more expensive or even suddenly dry up (Fábián - Vonnák 2014). This risk is especially acute in the case of short-term liabilities. Reliance on external savings and FX markets intensifies the volatility of exchange rates and increases expectations about interest rate spreads, which may undermine the economy's ability to raise funds in a crisis. The 2008 global financial crisis showed the risks of external vulnerability and thus also the importance of international FX reserves (Nagy - Palotai 2014; Csávás 2015).

\subsubsection{Interbank funding}

The over-reliance on funds from financial corporations may entail a major systemic risk, which, if it materialises, may have devastating consequences for the financial system and the real economy. In an economy with a high capacity and propensity to save, banks' primary source of finance is the deposits of households and small and medium-sized enterprises (so-called core liabilities). At the same time, in the expansion period of the credit cycle, when credit demand rises faster than the stock of available customer deposits, banks search for alternative sources of finance (socalled non-core liabilities) to supplement the above-mentioned core liabilities and maintain credit growth (Hahm et al. 2013). When short-term sources of finance are widespread, rollover risk increases (Dudley 2014). In times of uncertainty, financial institutions providing alternative financing may withdraw funds from the market, causing insufficient liquidity (Huang - Ratnovski 2011). Fear of contagion may lead to a drop in interbank lending and thus a meltdown of the credit market (lyer Peydro 2011).

\subsubsection{Off-balance sheet financing}

A too large currency mismatch in the banking system's balance sheet increases the banking system's reliance on off-balance sheet instruments (FX swaps) due to the exchange rate risk related to the change in the exchange rate, and this can produce 
systemic risks. In the case of long-term swaps, the main risk is the change in margin requirements. These increase considerably in the event of a depreciation in the exchange rate, generating additional FX demand and further increasing external vulnerability and the reliance on the swap market. In the case of short-term swap transactions, another risk is posed by the shorter maturity than for the typically long-term FX loans covered by the swap: this makes the rollover risk large, because in the absence of refinancing banks have an open foreign currency position, forcing them to acquire FX funds on the spot market (Páles et al. 2010). When it comes to short-term transactions, the drying-up of the swap market is a major threat mainly because if the FX necessary for repaying the foreign currency leg of the maturing FX swap is acquired on the spot market, that may lead to a depreciation of the exchange rate due to the fact that the spot market's volume is much smaller than the FX swap market. There is also the risk that such an acquisition of FX may be impossible in the case of system-wide demand due to the different volumes, and this may prevent the banks from honouring their payment obligations in FX.

\section{Lessons learnt from the global financial crisis in Hungary}

\subsection{The Hungarian banking system in the crisis}

The financial crisis that unfolded in 2007 seriously affected the Hungarian banking system, despite the fact that it played no role in the emergence of the crisis or its spillover. The country's financial vulnerability observed during the crisis arose mainly from the liquidity risk caused by the banking system's short-term FX financing need as well as the solvency risk caused by the FX loans. The financial system's weakness and the credit crunch deepened the recession and slowed the recovery (Nagy - Vonnák 2014).

The pre-crisis vulnerability is principally attributable to the nominal forint interest rates that were steadily high due to the economic policy in the early 2000s that encouraged consumption, as well as to inflation developments. Moreover, in the inconsistent monetary system of inflation targeting and the exchange rate band, the forint moved against the euro within a tight band, which provided a sense of exchange rate stability and resulted in an underestimation of the exchange rate risk. Households' previously deferred consumption demand and positive income expectations led to a rise in the demand for FX loans (Nagy - Vonnák 2014).

The rise in FX lending was coupled with an increase in risks, as banks gradually eased credit conditions in the competition for lending. This business model became increasingly unhealthy in the years leading up to the crisis, with banks relying more and more on foreign, short-term and mostly interbank funds and FX swaps while financing their lending operations. The expansionary economic policy and the Hungarian banking system's FX lending practices produced risky retail and 
corporate lending. The situation was compounded by the fact that the regulatory authorities sat idly by, as macroprudential responsibilities and powers were not clearly distributed among the institutions (Fábián - Vonnák 2014).

Prior to the crisis, banks financed a portion of FX lending from funds denominated in local currency or other foreign currencies, closing some of their on-balance sheet foreign currency positions with FX swap transactions. However, after the financial crisis unfolded, it became considerably harder to acquire FX liquidity, counterparty limits were tightened, and the forint's exchange rate volatility increased. Although the total average turnover on the Hungarian FX swap market did not fall dramatically, market liquidity contracted considerably for a few days, limiting access to FX liquidity. Maturities shortened and active engagement from parent banks was necessary to prevent turnover from plummeting. Implied forint yields became significantly detached from the floor of the interest rate corridor, so FX liquidity could only be acquired at high spreads relative to international interbank rates (Páles et al. 2010).

The development of the above vulnerabilities is illustrated by the change in some key indicators over time (Figure 2). It is clear that in addition to the rise of FX lending in banks' balance sheets, a financing model primarily resting on short-term FX funds and off-balance sheet risk-taking emerged in the Hungarian banking system before 2008. This was coupled with an ever tightening and overstretched liquidity position, which was indicated by the low and dropping level of operational liquidity reserves $^{3}$ before the crisis.

\footnotetext{
${ }^{3}$ The indicator used for monitoring banks' liquidity position, comprising banks' liquid assets and the contractual net flows of treasury transactions within a 30-day period (portfolio gap).
} 


\section{Figure 2 \\ Development of key banking system indicators relative to the balance sheet total}

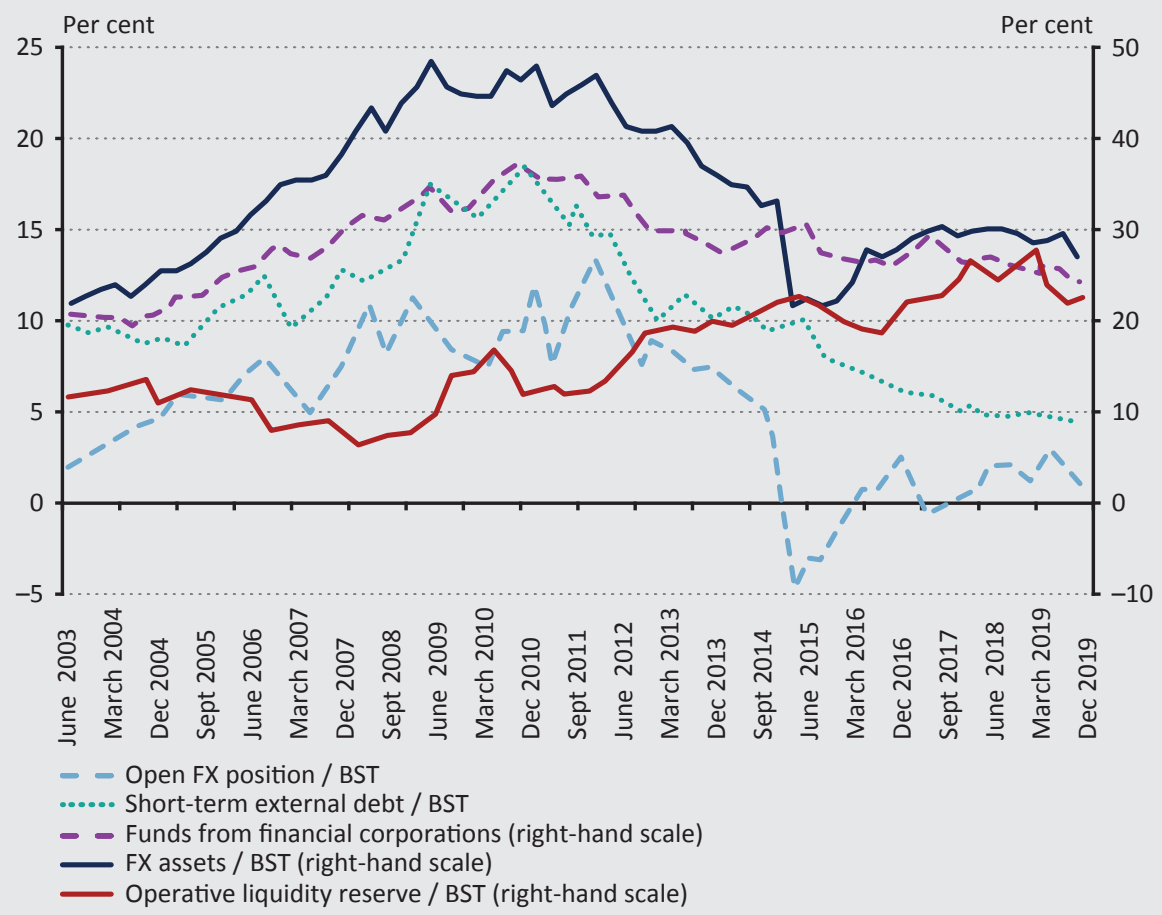

Note: $B S T=$ balance sheet total

Source: $M N B$

\subsection{The MNB's liquidity and funding regulatory toolkit}

In the European Union, macroprudential policy has rested on two elements of the Single Rulebook, the $\mathrm{CRR}^{4}$ and the CRD IV, ${ }^{5}$ as well as the related legal acts, since 2013. Macroprudential policy is primarily implemented and operated by Member State macroprudential authorities ${ }^{6}$ under the coordination of the European Systemic Risk Board (ESRB). Besides the instruments available under the EU regulatory framework, instruments developed within the national scope of competence can also be applied.

\footnotetext{
${ }^{4}$ Regulation (EU) No 575/2013 of the European Parliament and of the Council on prudential requirements for credit institutions and investment firms and amending Regulation (EU) No 648/2012

${ }^{5}$ Directive 2013/36/EU of the European Parliament and of the Council on access to the activity of credit institutions and the prudential supervision of credit institutions and investment firms, amending Directive 2002/87/EC and repealing Directives 2006/48/EC and 2006/49/EC

${ }^{6}$ Depending on the legal implementation, this may be the central bank, the supervisory authority, a ministry or even an independent body.
} 
From 1 October 2013, not only the supervisory, but also the resolution and macroprudential functions have been included in the MNB's mandate according to the decision of the Hungarian Parliament. Among other things, this was why the MNB assumed responsibility for the liquidity and funding instruments offered by the Single Rulebook, such as the LCR, the NSFR that enters into force on 28 June 2021, ${ }^{7}$ as well as the liquidity requirements that can be modified under the national flexibility measures pursuant to Article 458 of the CRR. In 2013, the MNB also obtained a mandate to issue decrees ${ }^{8}$, which allows it to stipulate macroprudential requirements for bank financing within the national scope of competence.

Therefore, with the exception of the FFAR, which was regulated in a government decree with the cooperation of the competent ministry in $2012,{ }^{9}$ the MNB designed several regulations at its own discretion. The relevant information on these regulations can be found in Table 1. Moreover, the LCR used at the EU level was also introduced early within the national scope of competence. The instruments listed here did not require any major adjustment on the part of banks because they were introduced at the bottom of the financial cycle, and they aim to prevent the future build-up of risks.

\begin{tabular}{|c|c|c|}
\hline \multicolumn{3}{|c|}{$\begin{array}{l}\text { Table } 1 \\
\text { Historical overview of liquidity and funding regulations introduced and revised by } \\
\text { the MNB }\end{array}$} \\
\hline & Effective date & Content \\
\hline Introduction of FFAR* & 1 July 2012 & $\begin{array}{l}\text { Introduction of an NSFR-type regulation taking into account } \\
\text { the features of the special Hungarian liquidity risks, and } \\
\text { managing currency risk as well as the risk arising from the } \\
\text { maturity mismatch between assets and liabilities, with } \\
\text { a minimum requirement of } 65 \text { per cent }\end{array}$ \\
\hline $\begin{array}{l}\text { Introduction of } \\
\text { Deposit Coverage } \\
\text { Ratio and Balance } \\
\text { Sheet Coverage Ratio* } \\
\end{array}$ & 1 July 2012 & $\begin{array}{l}\text { Introduction of regulations managing short-term, 30-day } \\
\text { liquidity risks }\end{array}$ \\
\hline 1st review of FFAR & 1 July 2014 & $\begin{array}{l}\text { Requirement in the form of an MNB decree, gradual tightening } \\
\text { and the extension of the institutional scope to EU branches }\end{array}$ \\
\hline $\begin{array}{l}\text { Phase-out of Deposit } \\
\text { Coverage Ratio and } \\
\text { Balance Sheet } \\
\text { Coverage Ratio }\end{array}$ & $\begin{array}{l}30 \text { September } \\
2015\end{array}$ & Repeal of the regulations due to the introduction of the LCR \\
\hline
\end{tabular}

\footnotetext{
${ }^{7}$ The introduction of the NSFR is laid down in the revised CRR, the CRR2: Regulation (EU) 2019/876 of the European Parliament and of the Council of 20 May 2019 amending Regulation (EU) No 575/2013 as regards the leverage ratio, the net stable funding ratio, requirements for own funds and eligible liabilities, counterparty credit risk, market risk, exposures to central counterparties, exposures to collective investment undertakings, large exposures, reporting and disclosure requirements, and Regulation (EU) No 648/2012

${ }^{8}$ Act CXXXIX of 2013 on the Magyar Nemzeti Bank.

${ }^{9}$ In the absence of the MNB's powers to issue decrees, the FFAR, DCR and BCR ratios introduced on 1 July 2012 were regulated by the government at the MNB's proposal.
} 


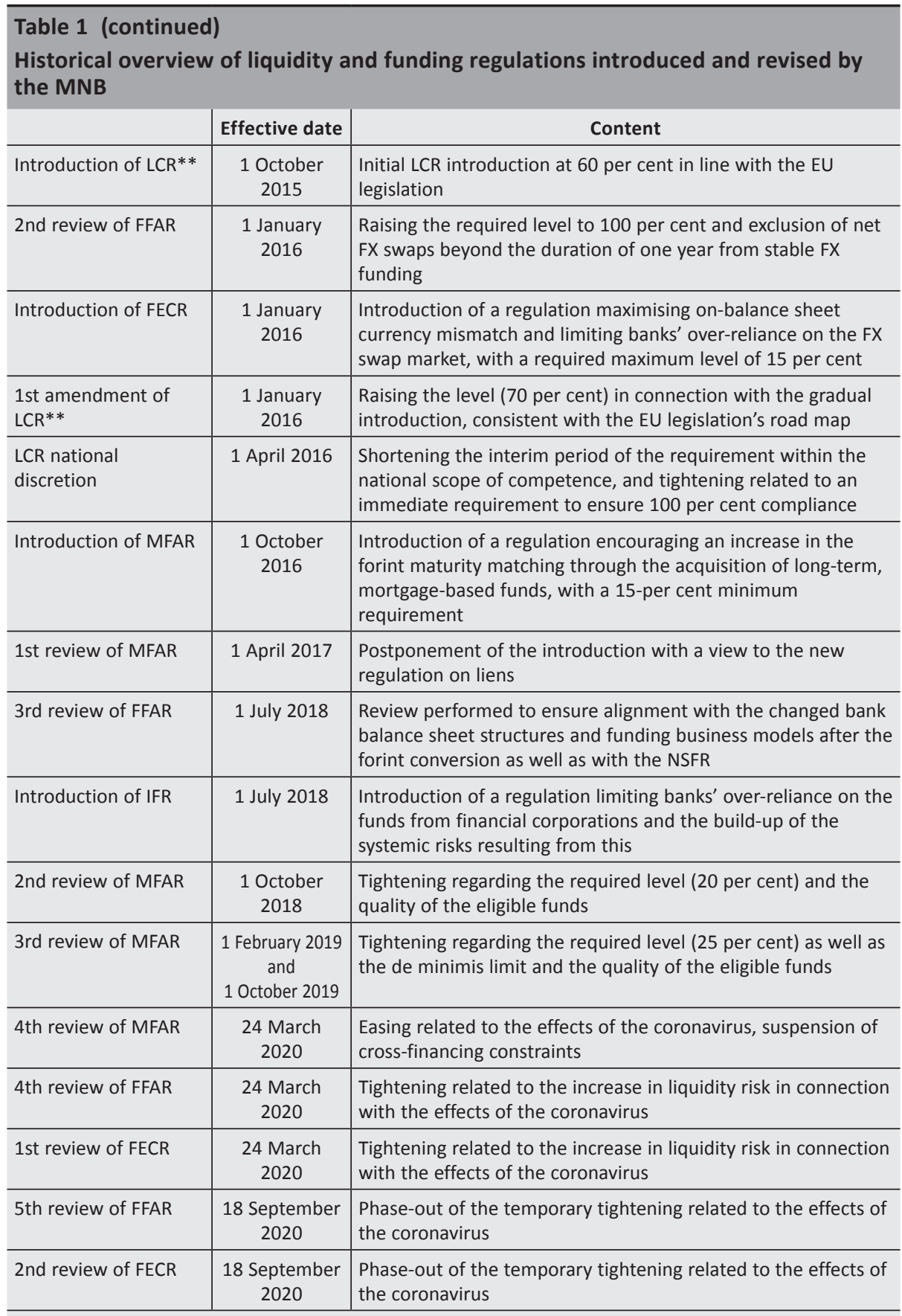

Note: *In the absence of the MNB's macroprudential mandate, it was introduced by a government decree in cooperation with the MNB. ** Prescribed by a directly applicable EU regulation.

Source: $M N B$ 
By 2018, a toolkit was available for mitigating and preventing liquidity and funding risks with complementary elements, which would have had a significant effect on the systemic risks that built up prior to the crisis, had they been introduced earlier. However, only the requirements that are relevant for our backtesting exercise are described below, in other words, those that have the greatest impact on the risks related to short-term external financing and FX lending. ${ }^{10}$

- Liquidity Coverage Ratio: The liquidity coverage requirement expects banks to hold a sufficient quantity and quality of liquid assets to cover any net outflows assumed in the case of a short-term (30-day) liquidity shock. Compliance with the liquidity coverage requirement can mainly be ensured by increasing the stock of highly liquid assets and by raising longer-term funds.

$$
\text { LCR }=\text { Liquid assets } / \text { Net liquidity outflows }>100 \%
$$

- Foreign Exchange Funding Adequacy Ratio: The instrument expects institutions to hold a sufficient amount of stable FX funds aligned with their FX assets that require stable financing (mostly long-term, illiquid FX assets). The impact mechanism of the regulation is twofold. It reduces the risks stemming from on-balance sheet currency mismatches and limits the rise in off-balance sheet liabilities. In addition, with respect to FX liabilities, it encourages banks to use funds embodying stable, long-term financing, thereby reducing the maturity mismatches on the balance sheets of credit institutions. The FFAR can also affect off-balance sheet guarantees. Supplemented by other instruments, such as the FECR, the instrument can also mitigate the external vulnerability of the banking sector.

$$
\begin{gathered}
\text { FFAR }=\text { Weighted sum of available stable FX funding / } \\
\text { Required stable FX funding }>100 \%
\end{gathered}
$$

- Foreign Exchange Coverage Ratio: The regulation imposes a limit on the degree of currency mismatches between assets and liabilities relative to the balance sheet total. The reduction of on-balance sheet currency mismatches also reduces institutions' reliance on off-balance sheet instruments, mainly FX swaps, which, in turn, lowers the risks stemming from these instruments (rollover, liquidity and margin call risks). Supplemented by other instruments, such as the FFAR, the

\footnotetext{
${ }^{10}$ The Deposit Coverage Ratio and the Balance Sheet Coverage Ratio that targeted short-term liquidity risks and were repealed upon the introduction of the LCR, and the Mortgage Funding Adequacy Ratio (MFAR) designed to ensure forint maturity matching, will not be described here, since these were not included in the backtesting exercise. As the instruments repealed upon the introduction of the LCR managed risks identical to those in the LCR requirement, it seemed sufficient to include the LCR in the analysis. The MFAR seeks to manage the rising forint maturity mismatch in the wake of the forint conversion caused by the appearance of large amounts of long-term forint-denominated mortgage loans on banks' balance sheets, and this risk was negligible before the crisis due to the smaller share of forint-denominated mortgage loans and the higher proportion of mortgage bonds.
} 
instrument can also mitigate risks stemming from the vulnerability of external finance.

$$
F E C R=A B S(F X \text { assets }-F X \text { liabilities }) / \text { Balance sheet total }<15 \%{ }^{11}
$$

- Interbank Funding Ratio: The regulation limits the sum of the funds from financial corporations weighted by currency and residual maturity relative to liabilities. The targeted measure can effectively prevent the over-reliance on funds from financial corporations.

$$
\begin{gathered}
I F R=\text { Weighted sum of the funds from financial corporations } / \\
\qquad(\text { Balance sheet total }- \text { Equity })<30 \%
\end{gathered}
$$

Overall, the regulations can exert an impact on practically the whole balance sheet of banks, capturing one specific funding or liquidity aspect each, but also complementing each other (Figure 3).

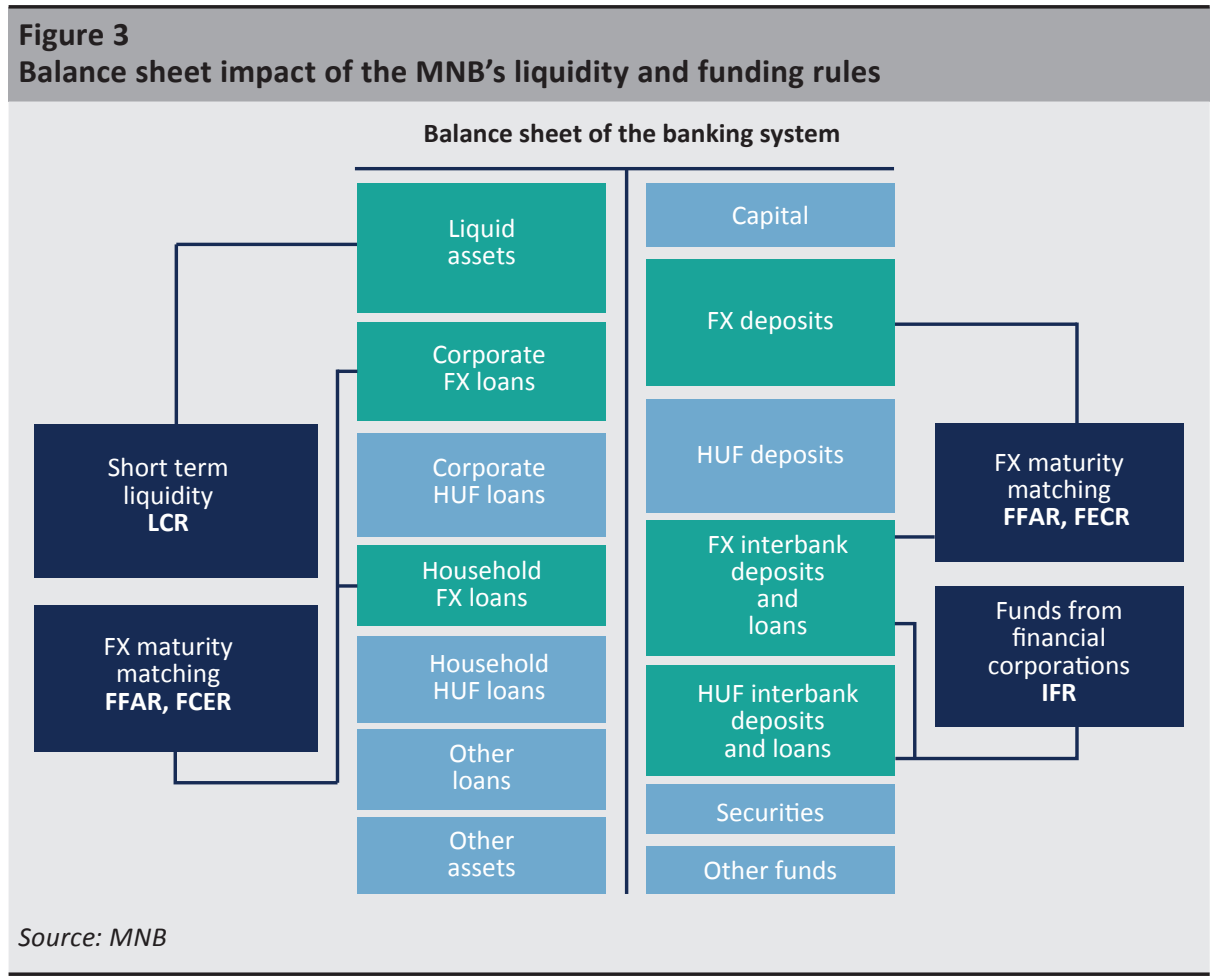

${ }^{11}$ Due to the rising risks in connection with the coronavirus pandemic, the permitted level was temporarily lowered to 10 per cent between 24 March 2020 and 17 September 2020. 


\section{Backtesting certain liquidity and funding regulations}

\subsection{Methodology}

Had the chosen funding rules capturing the different dimensions of liquidity and FX maturity mismatches been introduced before the crisis, the institutions concerned would have had to adjust to ensure compliance, provided they had not been compliant before. The greatest methodological challenge is that one cannot retroactively determine the exact adjustment channel the banks under review would have used. In this case, stochastic models, which are often used for assessing and testing regulatory measures, do not provide a solution. These models (such as difference in differences, propensity score matching and the synthetic control method) identify control groups and treatment groups and establish their dynamics relative to each other as the effect of the intervention. However, the introduction of the macroprudential framework affected the entire Hungarian banking system uniformly, therefore no appropriate control group can be found. Furthermore, an international outlook would not be of much use either, since the earliest point in the period under review assumes that the macroprudential framework was introduced in 2003. At that time, the ideas of a comprehensive macroprudential policy or the introduction and application of dedicated macroprudential instruments were not floated in other countries either, so no benchmark can be pinpointed relative to which the changes in the Hungarian banking system could be compared.

To get around these problems, a wholly deterministic approach is used: a set of assumptions are made that provide a good approximation of the banking system's adjustment options. Since there is no way to determine how the individual banks would have responded to the regulations listed above, the most viable and costeffective opportunities are collected by the authors. Of course, no claim is made that all the banks under review would have chosen the adjustment method determined here, the authors merely strove to appropriately approximate the most efficient ways of adjustment at a systemic level. It should be underlined though that the calculated values only provide a rough estimation about the effects of the rules under review.

Potential simple adjustment methods that result in a substantial improvement in the indicators and are not so limited by balance sheet constraints were defined, and they were ranked on an expert basis by viability and cost. The adjustment is based on the ranking: banks adjust using the adjustment method ranked first until the relevant limit is reached, then they switch to the method ranked next. The adjustment continues until banks comply with all the requirements for the indicators or as long as they are able to improve their indicators with the pre-defined 
adjustment methods. Although we sought to take all aspects into account with due care during the ranking, to minimise the uncertainties arising from expert-based ranking the study focuses on the results that are independent from the ranking determined here, or depend on it to a small degree only. With the exception of the FFAR, ${ }^{12}$ the adjustment to the indicators was examined based on the requirements in effect prior to the temporary amendment due to the coronavirus pandemic.

To ensure compliance with the funding indicators, banks would have been forced to adjust by transforming their funding structure on the liabilities side or phasing out FX lending on the assets side. Two scenarios are distinguished according to whether banks are able to adapt on the liabilities side without constraints, or whether it is also necessary to reduce the stock of FX loans. In the first scenario, with only a liability-side adjustment, banks increase the amount of their stable FX funds to improve currency and maturity matching, by converting their existing funds to foreign currency, extending maturities or obtaining new long-term FX funds (Table 2). In this scenario, it is assumed that method A4, the acquisition of long-term FX funds, has no constraint.

The adjustment's steps and its effects on the indicators are shown in Table 2: in the case of Adjustment A1, converting HUF 100 of interbank forint-denominated external funds with maturities of 1-2 years to $\mathrm{FX}$, increases the numerator of the IFR by HUF 10 due to the less favourable weighting of FX funds, thereby slightly deteriorating the indicator's value. However, this transaction improves the value of the FFAR and the FECR, raising the numerator of the FFAR by HUF 100 and reducing the numerator of the FECR by HUF 100 . This adjustment is performed by the bank until it complies with all the indicators or until it runs out of its interbank forint-denominated external funds with maturities of 1-2 years. If no more such funds are available, but the bank does not comply with all the indicators, it starts the next adjustment step (A2).

\footnotetext{
12 In the case of the FFAR, the FFAR effective before 1 July 2018 was used in the calculations since it is easier to estimate the FFAR at that time in retrospect.
} 


\begin{tabular}{|c|c|c|c|c|c|c|}
\hline \multicolumn{7}{|c|}{$\begin{array}{l}\text { Adjustment methods used for adjustment on the liabilities side only, their assumed } \\
\text { order, and effects on the indicators }\end{array}$} \\
\hline \multicolumn{3}{|c|}{ ADJUSTMENT METHOD } & \multicolumn{4}{|c|}{$\begin{array}{l}\text { EFFECT OF ADJUSTMENT METHOD ON THE } \\
\text { INDICATORS }\end{array}$} \\
\hline AM & Asset & Liability & IFR & FFAR & FECR & LCR* $^{*}$ \\
\hline A1 & None & $\begin{array}{l}\text { Converting interbank } \\
\text { forint-denominated } \\
\text { external funds with } \\
\text { maturities of } 1-2 \text { years } \\
\text { to FX }\end{array}$ & $\begin{array}{l}\text { Numerator } \\
\uparrow 10 \%\end{array}$ & $\begin{array}{c}\text { Numerator } \\
\uparrow 100 \%\end{array}$ & $\begin{array}{l}\text { Numerator } \\
\downarrow 100 \%\end{array}$ & 0 \\
\hline $\mathrm{A} 2$ & None & $\begin{array}{l}\text { Converting interbank } \\
\text { forint-denominated } \\
\text { external funds with } \\
\text { maturities of over } 2 \text { years } \\
\text { to FX }\end{array}$ & 0 & $\begin{array}{c}\text { Numerator } \\
\uparrow 100 \%\end{array}$ & $\begin{array}{c}\text { Numerator } \\
\downarrow 100 \%\end{array}$ & 0 \\
\hline $\mathrm{A} 3$ & None & $\begin{array}{l}\text { Extending the maturities of } \\
\text { interbank FX-denominated } \\
\text { external funds with } \\
\text { maturities of } 0-1 \text { year to } \\
\text { over } 2 \text { years }\end{array}$ & $\begin{array}{l}\text { Numerator } \\
\downarrow 100 \%\end{array}$ & $\begin{array}{c}\text { Numerator } \\
\uparrow 100 \%\end{array}$ & 0 & 0 \\
\hline A4 & $\begin{array}{l}\text { Purchasing forint- } \\
\text { denominated } \\
\text { government } \\
\text { securities }\end{array}$ & $\begin{array}{l}\text { Acquisition of interbank } \\
\text { FX-denominated external } \\
\text { funds with maturities of } \\
\text { over } 2 \text { years }\end{array}$ & $\begin{array}{l}\text { Denominator } \\
\uparrow 100 \%\end{array}$ & $\begin{array}{c}\text { Numerator } \\
\uparrow 100 \%\end{array}$ & $\begin{array}{c}\text { Numerator } \\
\downarrow 100 \% \\
\text { Denominator } \\
\uparrow 100 \%\end{array}$ & $\begin{array}{l}\text { Numerator } \\
\uparrow 100 \%\end{array}$ \\
\hline \multicolumn{7}{|c|}{$\begin{array}{l}\text { Note: *The exact effect on the outflows and inflows, where relevant, cannot be estimated. The change } \\
\text { in the LCR only reflects the change in liquid asset holdings. In addition, the columns show the effect on } \\
\text { the given indicator in the case of the different adjustment methods, as a percentage of the adjustment, } \\
\text { i.e. the extent by which one unit of adjustment modifies the numerator or denominator of the indicators, } \\
\text { thereby reducing or improving compliance with the regulation. The red shading indicates deterioration } \\
\text { in the indicator, while green denotes improvement. A positive initial value was assumed in the case of } \\
\text { the FECR. }\end{array}$} \\
\hline
\end{tabular}

In the second scenario, when asset-side adjustment is also included, the opportunities for method A4, i.e. acquisition of long-term FX funds, are limited, since it can be assumed that Hungarian banks cannot obtain unlimited FX funds. According to our assumption, banks can only obtain half the amount of funds necessary in the first scenario, which makes it necessary to involve asset-side adjustment affecting FX loan holdings as well (Table 3). It is assumed that the FX loan holdings would be reduced by converting the loans to forints. 


\begin{tabular}{|c|c|c|c|c|c|c|}
\hline \multicolumn{3}{|c|}{ ADJUSTMENT METHOD } & \multicolumn{4}{|c|}{$\begin{array}{l}\text { EFFECT OF ADJUSTMENT METHOD ON THE } \\
\text { INDICATORS }\end{array}$} \\
\hline AM & Asset & Liability & IFR & FFAR & FECR & LCR* \\
\hline A1 & None & $\begin{array}{l}\text { Converting interbank } \\
\text { forint-denominated } \\
\text { external funds with } \\
\text { maturities of } 1-2 \text { years } \\
\text { to FX }\end{array}$ & $\begin{array}{l}\text { Numerator } \\
\uparrow 10 \%\end{array}$ & $\begin{array}{l}\text { Numerator } \\
\uparrow 100 \%\end{array}$ & $\begin{array}{l}\text { Numerator } \\
\downarrow 100 \%\end{array}$ & 0 \\
\hline A2 & None & $\begin{array}{l}\text { Converting interbank } \\
\text { forint-denominated } \\
\text { external funds with } \\
\text { maturities of over } 2 \text { years } \\
\text { to FX }\end{array}$ & 0 & $\begin{array}{l}\text { Numerator } \\
\uparrow 100 \%\end{array}$ & $\begin{array}{l}\text { Numerator } \\
\downarrow 100 \%\end{array}$ & 0 \\
\hline A3 & None & $\begin{array}{l}\text { Extending the maturities of } \\
\text { interbank FX-denominated } \\
\text { external funds with } \\
\text { maturities of } 0-1 \text { year to } \\
\text { over } 2 \text { years }\end{array}$ & $\begin{array}{l}\text { Numerator } \\
\downarrow 100 \%\end{array}$ & $\begin{array}{l}\text { Numerator } \\
\uparrow 100 \%\end{array}$ & 0 & 0 \\
\hline A4 & $\begin{array}{l}\text { Purchasing forint- } \\
\text { denominated } \\
\text { government } \\
\text { securities }\end{array}$ & $\begin{array}{l}\text { Acquisition of interbank } \\
\text { FX-denominated external } \\
\text { funds with maturities of } \\
\text { over } 2 \text { years }\end{array}$ & $\begin{array}{c}\text { Denominator } \\
\uparrow 100 \%\end{array}$ & $\begin{array}{l}\text { Numerator } \\
\uparrow 100 \%\end{array}$ & $\begin{array}{l}\text { Numerator } \\
\downarrow 100 \% \\
\text { Denominator } \\
\uparrow 100 \%\end{array}$ & $\begin{array}{c}\text { Numerator } \\
\uparrow 100 \%\end{array}$ \\
\hline A5 & $\begin{array}{l}\text { Reduction of retail } \\
\text { FX mortgage loan } \\
\text { holdings (forint } \\
\text { conversion) }\end{array}$ & $\begin{array}{l}\text { None (off-balance sheet } \\
\text { effect, in the FX swap } \\
\text { holdings) }\end{array}$ & 0 & $\begin{array}{c}\text { Denominator } \\
\downarrow 65 \%\end{array}$ & $\begin{array}{l}\text { Numerator } \\
\downarrow 100 \%\end{array}$ & 0 \\
\hline A6 & $\begin{array}{l}\text { Reduction of other } \\
\text { retail FX loan } \\
\text { holdings (forint } \\
\text { conversion) }\end{array}$ & $\begin{array}{l}\text { None (off-balance sheet } \\
\text { effect, in the FX swap } \\
\text { holdings) }\end{array}$ & 0 & $\begin{array}{l}\text { Denominator } \\
\quad \downarrow 85 \%\end{array}$ & $\begin{array}{l}\text { Numerator } \\
\downarrow 100 \%\end{array}$ & 0 \\
\hline
\end{tabular}

The adjustment methods presented so far help the adjustment of the banks that financed their FX lending mostly from forint-denominated funds and, to a lesser extent, short-term interbank FX funds. However, a smaller portion of banks operated with a different business model, which resulted in a reverse currency mismatch. These institutions, typically the local branches of large Western European banks, obtained FX funds more cheaply and in larger quantities than their Hungarian peers, then they swapped them to forints with Hungarian counterparties. Therefore they usually had excess FX funds and a FECR below -15 per cent. ${ }^{13}$ The adjustment of such institutions required the definition of special adjustment methods, since their FECR compliance would only have been deteriorated by the adjustment methods defined above (Table 4).

${ }^{13}$ Although the regulation governs the absolute value of the difference between FX assets and FX liabilities, this paper does not employ absolute values when calculating the FECR values, the indicator is used with a sign instead. This is because different adjustment methods are necessary in the case of positive and negative values of the indicator, i.e. in the case of surplus FX assets and surplus FX liabilities. 
Table 4

Adjustment methods of the banks with a FECR of under "-15" per cent, their order, and effects on the indicators

ADJUSTMENT METHOD

EFFECT OF ADJUSTMENT METHOD ON THE INDICATORS

\begin{tabular}{|c|c|c|c|c|c|c|}
\hline AM & Asset & Liability & IFR & FFAR & FECR & LCR $^{*}$ \\
\hline B1 & $\begin{array}{l}\text { Reduction of } \\
\text { forint-denomina- } \\
\text { ted liquid assets } \\
\text { (government } \\
\text { securities) }\end{array}$ & $\begin{array}{l}\text { Reduction of interbank } \\
\text { FX-denominated external } \\
\text { funds with maturities of } \\
0-1 \text { year (banks and their } \\
\text { parent banks swap back } \\
\text { the FX loan received from } \\
\text { the parent bank and swap- } \\
\text { ped to forints with a local } \\
\text { bank, and banks repay the } \\
\text { FX loan) }\end{array}$ & $\begin{array}{c}\text { Numerator } \\
\downarrow 100 \% \\
\text { Denominator } \\
\downarrow 100 \%\end{array}$ & 0 & $\begin{array}{c}\text { Numerator } \\
\uparrow 100 \% \\
\text { Denominator } \\
\downarrow 100 \%\end{array}$ & $\begin{array}{c}\text { Numerator } \\
\downarrow 100 \%\end{array}$ \\
\hline B2 & $\begin{array}{l}\text { FX government } \\
\text { bond, central bank } \\
\text { bond purchases }\end{array}$ & $\begin{array}{l}\text { Acquisition of interbank } \\
\text { FX-denominated external } \\
\text { funds with maturities of } \\
\text { over } 2 \text { years }\end{array}$ & $\begin{array}{c}\text { Denominator } \\
\uparrow 100 \%\end{array}$ & $\begin{array}{c}\text { Numerator } \\
\uparrow 100 \% \\
\text { Denominator } \\
\uparrow 5 \%\end{array}$ & $\begin{array}{c}\text { Denominator } \\
\uparrow 100 \%\end{array}$ & $\begin{array}{c}\text { Numerator } \\
\uparrow 100 \%\end{array}$ \\
\hline
\end{tabular}

Note: *The exact effect on the outflows and inflows, where relevant, cannot be estimated. The change in the LCR only reflects the change in liquid asset holdings. Also, see the note to Table 2. The red shading indicates deterioration in the indicator, while green denotes improvement. A negative initial value was assumed in the case of the FECR.

Institutions may face certain balance sheet constraints with the different adjustment methods (Table 5). Therefore banks can only use the different methods until the specific balance sheet items are exhausted: for example in method $A 1$, they can only convert their interbank forint-denominated external funds with maturities of 1-2 years to FX as long as they have such funds on their balance sheets. In view of the assumed adjustment methods, there are four balance sheet items that come with constraints, two on the liabilities side, and two on the assets side. There are no balance sheet constraints in the B2 adjustment method and in the A4 method in the first scenario. In the second scenario, besides the constraints in the first scenario, method A4 is constrained too, because it is assumed that banks can only access half the amount necessary from external funds, which calls for an asset-side adjustment.

\section{Table 5}

Constraints on the liabilities and assets side of the balance sheet in the case of the different adjustment methods, and their content

\begin{tabular}{l|l|l|c}
\hline \multicolumn{1}{|c|}{ Balance sheet constraint } & \multicolumn{1}{|c}{ Content and reason } & $\begin{array}{c}\text { Adjustment } \\
\text { method }\end{array}$ \\
\hline $\begin{array}{l}\text { Interbank external forint- } \\
\text { denominated funds with } \\
\text { maturities of 1-2 years and } \\
\text { over } \mathbf{2} \text { years }\end{array}$ & $\begin{array}{l}\text { When long-term forint-denominated funds are replaced } \\
\text { with long-term FX funds, which can improve the FFAR } \\
\text { and the FECR. }\end{array}$ & A1, A2 \\
\hline $\begin{array}{lll}\text { Interbank external FX funds } \\
\text { with maturities of 0-1 year }\end{array}$ & $\begin{array}{l}\text { Only the originally short-term interbank FX deposits } \\
\text { and outstanding borrowings that are not demand } \\
\text { deposits were included, because these are probably } \\
\text { the holdings whose maturities can easily be extended } \\
\text { by banks. }\end{array}$ & A3, B1 \\
\hline $\begin{array}{l}\text { Retail FX loans } \\
\text { Including retail FX mortgage loans with real estate } \\
\text { collateral (housing and home equity loans) and other } \\
\text { retail FX loans. }\end{array}$ & A5, A6 \\
\hline $\begin{array}{l}\text { Forint-denominated liquid } \\
\text { assets }\end{array}$ & The LCR's numerator was taken into account. & B1 \\
\hline
\end{tabular}




\subsection{Compilation of the data, estimation of the indicators}

To perform the calculations, the regulatory indicators of the individual banks had to be collected on the one hand, and the balance sheet items triggering the adjustment constraints had to be compiled on the other. The necessary data were derived from the supervisory reporting submitted by the banks. As regards the regulatory ratios, no related reporting was available since the regulations were not in place before the crisis. What is more, a much smaller data set less suited for the estimation of the indicators was available for the period prior to the crisis. Therefore, to tackle the shortage of data and to simplify matters, the indicators could only be approximated, with various specific limitations. The more complex an indicator, the more limitations were needed:

- In the case of the LCR, the main goal was to produce a simpler indicator by capturing the main items.

- With respect to the FFAR, the calculation with original maturities instead of residual maturities, and for some items, estimating the $\mathrm{FX}$ ratio and off-balance sheet liabilities due to the lack of data with a currency breakdown posed difficulties.

- With regard to the IFR, the problem was the lack of data on residual maturities and the estimation of the exemptible preferential items in the regulation.

- In the case of liability-side balance sheet constraints, original maturities were used because the residual maturities were not available for the data pertaining to the period before the crisis.

The estimation was made for a smaller set of banks, 13 Hungarian large banks, including major branches. The data were compiled and estimated for all six years between 2003 and 2008. The estimates were produced at the individual (unconsolidated) level, due to simplification and data constraints.

\section{Findings}

The change and composition of the individual indicators as well as the changes in the short-term interbank external FX funds and retail FX loans in each year and across years were examined by running simulations of the adjustment methods on the compiled data. If some realistic assumptions are met (for example that banks would first mainly adjust on the liabilities side and that at least part of their existing liabilities would be exchanged for long-term FX funds before acquiring them by increasing their balance sheets), minor changes to the ranking of the adjustment methods would not materially influence the results presented here and thus the main conclusions. 


\subsection{Compliance with regulation}

According to the methodology and the adjustment methods described here, all banks under review would have moved closer to the regulatory limits, but not all banks would have achieved full compliance. This would probably have required other adjustment methods that would have made the methodology significantly more complex, and this would not have been reasonable in view of the aim and result of the calculations.

In the first scenario permitting an unlimited liability-side adjustment, all banks would have been able to comply with all ratios in every year (Figure 4). In the second scenario complemented with asset-side adjustment, a large portion of banks would have been unable to achieve full compliance by reducing household FX loan holdings due to their limited nature. Therefore, banks would only have been able to improve their ratios. This compliance issue practically only arose in the case of the FFAR. In the early 2000s, the high level of non-compliance is attributable to the fact that retail FX loan holdings were small and building up slowly at that time, corporate FX loans were more typical. Eliminating them suddenly would have had devastating consequences for the operation of banks and the broader economy, therefore this was not included among the potential adjustment methods. It also has to be added that in reality, the introduction of such a regulation is preceded by a long preparation period, which may last for years, giving banks enough time to gradually overhaul even their entire asset and liability structure.

Figure 4
Number of banks complying with regulation before and after adjustment in first and
second scenario

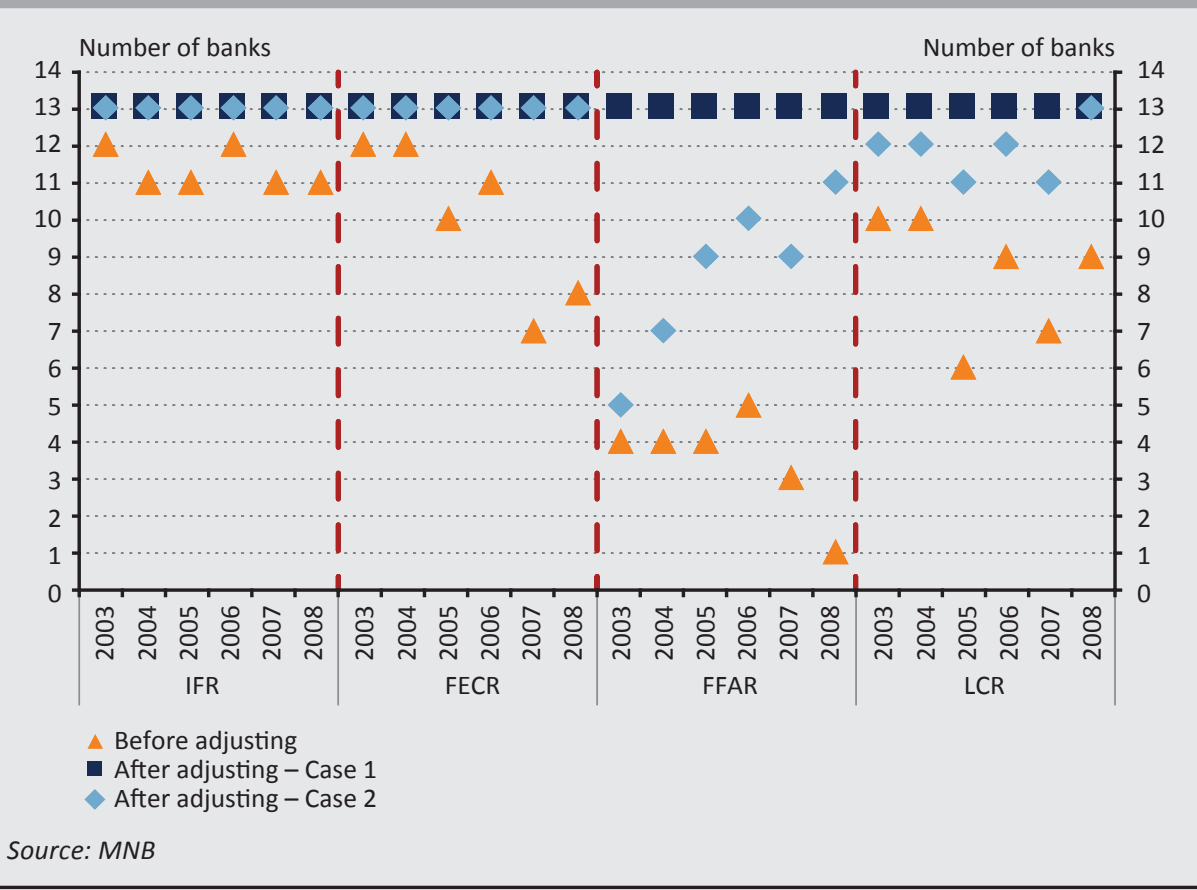


Since the IFR is even currently preventive and targets extreme banking models, only a few banks, two branches in total, would have been forced to adjust, achieving full compliance. There were no differences between the scenarios, since in the case of the IFR, the compliance with the strictly liability-side requirement cannot be improved with an asset-side adjustment. In the case of the FECR, more and more banks would have been forced to adjust over time, but all banks would have been able to come within the limits in both scenarios. The greatest adjustment would have been required by banks in the case of the FFAR, as almost all banks, with only a few exceptions, would have been forced to adapt. After the adjustment, compliance would only have been achieved by all banks in the first scenario, since the second scenario would have required a major reduction in retail FX loans, and most banks would have been unable to meet the FFAR requirements under such conditions. Most banks would have been able to adjust to meet the LCR requirements, although in the second scenario fewer institutions would have achieved this, because there would have been less room for improving the LCR as the adjustment affected liquid assets less. ${ }^{14}$

According to the results of the backtesting, over time, as the beginning of the crisis approached, banks would have needed to adjust more and more. While the introduction of the regulatory instruments under review would have required only a small adjustment from most banks in 2003, the same would have called for a major adjustment in 2008. Although the use of certain adjustment methods and the exact extent of total adjustment may depend on the methods' ranking, it can be argued that banks would have been able to adjust the most by purchasing government securities from long-term interbank external funds, extending the maturities of short-term external FX funds and, in the case of an asset-side adjustment, by converting retail $\mathrm{FX}$ loans into forint (Figure 5).

\footnotetext{
${ }^{14}$ The impact on the development of the indicators and the distribution among banks by regulation is shown in Figures $10-13$ of the Annex.
} 


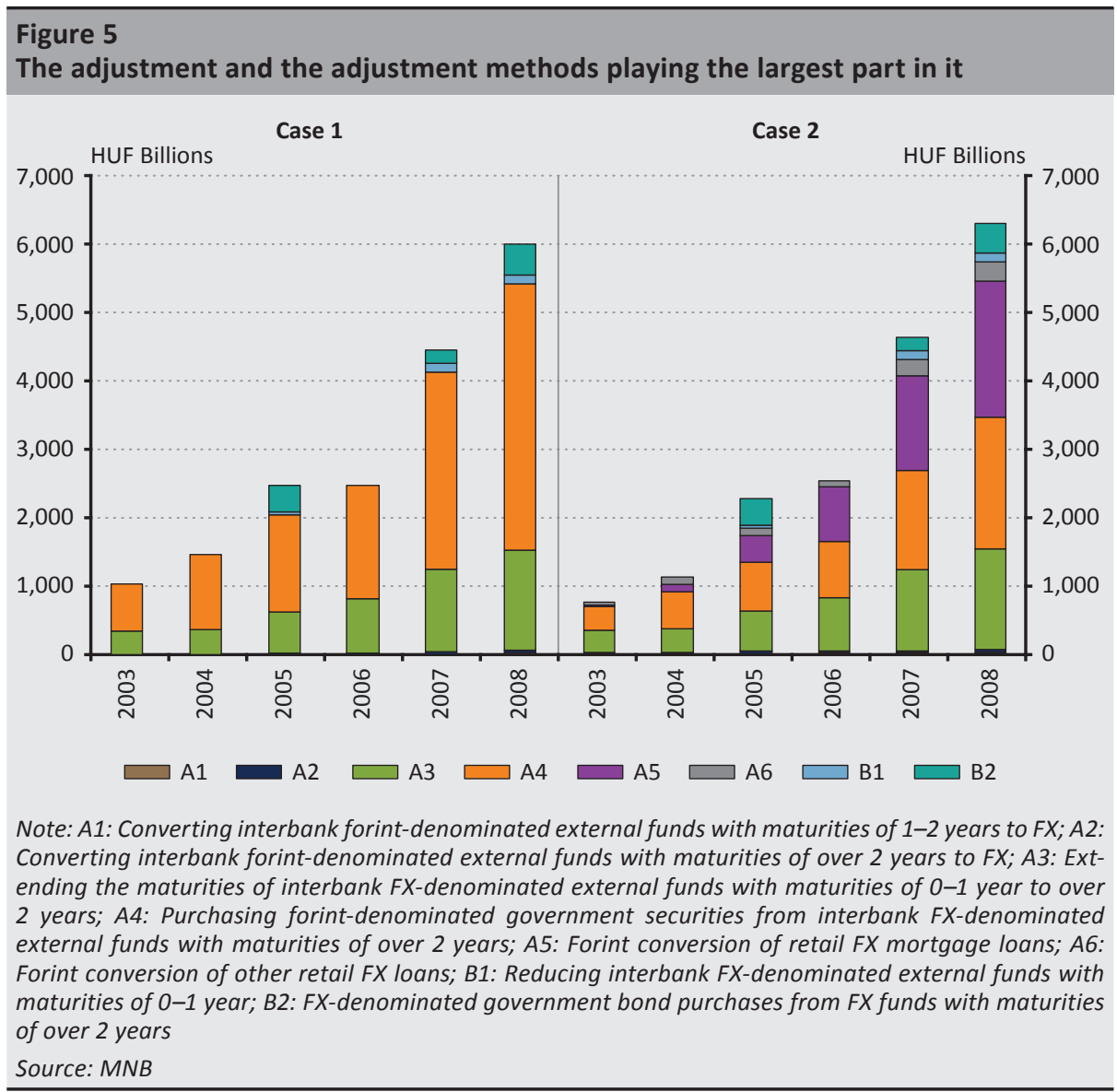

\subsection{Effects on external vulnerability and lending}

With respect to macroeconomic level effects, if the regulations had been introduced before the crisis, the level of short-term external debt and thus also the external vulnerability of the national economy could have been kept much lower (Figure 6). The short-term interbank external debt could have been considerably lower in both scenarios and in all the years under review, especially in the years leading up to the crisis, which would have resulted in lower vulnerability and a much smaller international reserve requirement. With an asset-side adjustment, the contraction in short-term external debt would have been coupled with a massive reduction in outstanding loan portfolio. At the same time, it is important to add that introducing the measures directly before the crisis would have come too late and would have caused a shock, and the cost of compliance would have been high due to the significant adjustment need, which highlights the importance of timing. 


\section{Figure 6 \\ Impact of the introduction of the regulation on banks' short-term external debt and FX loans}

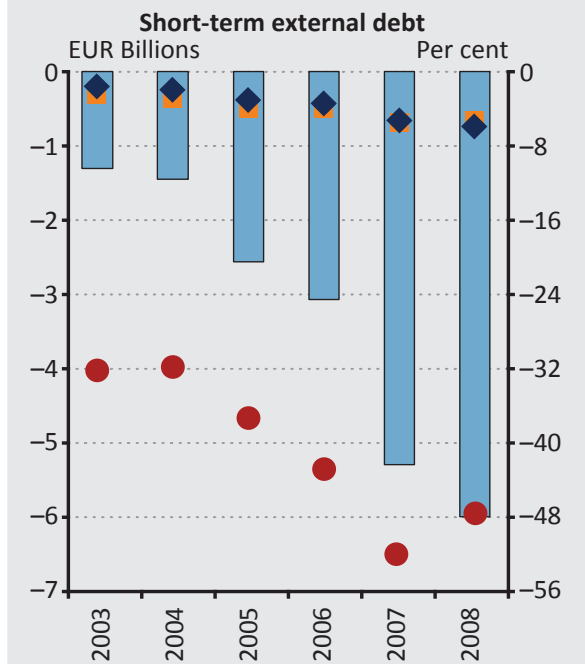

$\square$ Reduction of short-term FX external debt

- Compared to short-term external debt of banks (right-hand scale)

- Compared to balance sheet total (right-hand scale)

- Compared to GDP (right-hand scale)

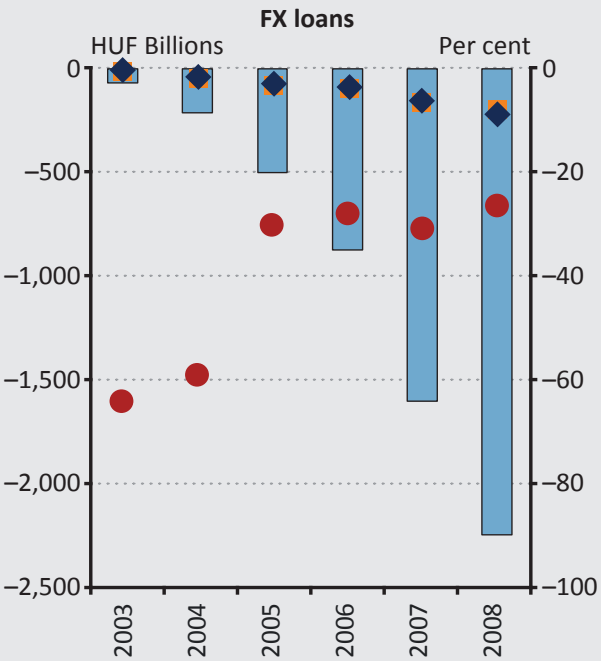

Reduction of household FX loans

- Compared to total household FX loans (right-hand scale)

- Compared to balance sheet total (right-hand scale)

- Compared to GDP (right-hand scale)

Note: If the instruments had taken effect in the given year. While the reduction in short-term external debt is true for both scenarios, FX loan holdings would only have shrunk in the second case.

Source: $M N B$

The regulation would have required institutions to cut short-term interbank external FX debt by up to 3-6 per cent of the balance sheet total on average (Figure 7), reaching 30 per cent of the balance sheet total at certain institutions, especially in the case of the branches involved in so-called carry trade ${ }^{15}$ activities or the business models relying heavily on short-term external funds from the parent bank. Moreover, several banks would have needed to eliminate their entire retail FX loan portfolio. At the time when FX loans started to become popular, the regulation would have required an adjustment amounting to 5-9 per cent of the balance sheet total on average, and this could have been close to 20 per cent in the case of four banks.

\footnotetext{
${ }^{15}$ These transactions involve asset purchases (or lending for example) from leverage. In the case of an FX market carry trade, borrowing in one currency at lower rates is coupled with an investment (e.g. lending) in another currency at a higher rate.
} 


\section{Figure 7 \\ Change and distribution of short-term external debt and FX loans relative to the balance sheet total}

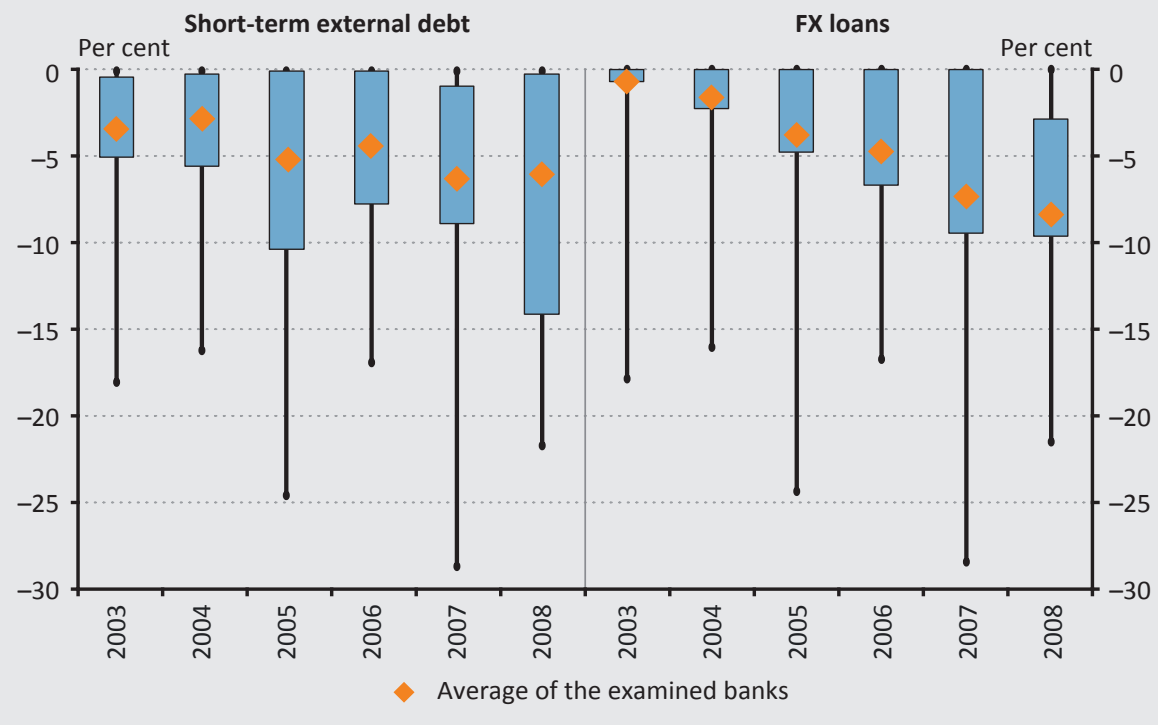

Note: If the instruments had taken effect in the given year. Minimum and maximum, lower and upper quartile values. While the reduction in short-term external debt is true for both scenarios, FX loan holdings would only have shrunk in the second case.

Source: MNB

If the regulation had been introduced by the competent authority in 2003 and it had been maintained in the years after that, it would have crowded out a large amount of short-term external funds, albeit varying quantities in each year, as can be seen from the actual development of short-term external debt (Figure 8). The actual credit path suggests that the same would have happened with retail FX loans. However, due to the large spread of forint loans, the FX loans crowded out by the regulation could only have been offset in part by increasing forint loan holdings or by the forint conversion mentioned in connection with the adjustment methods. 

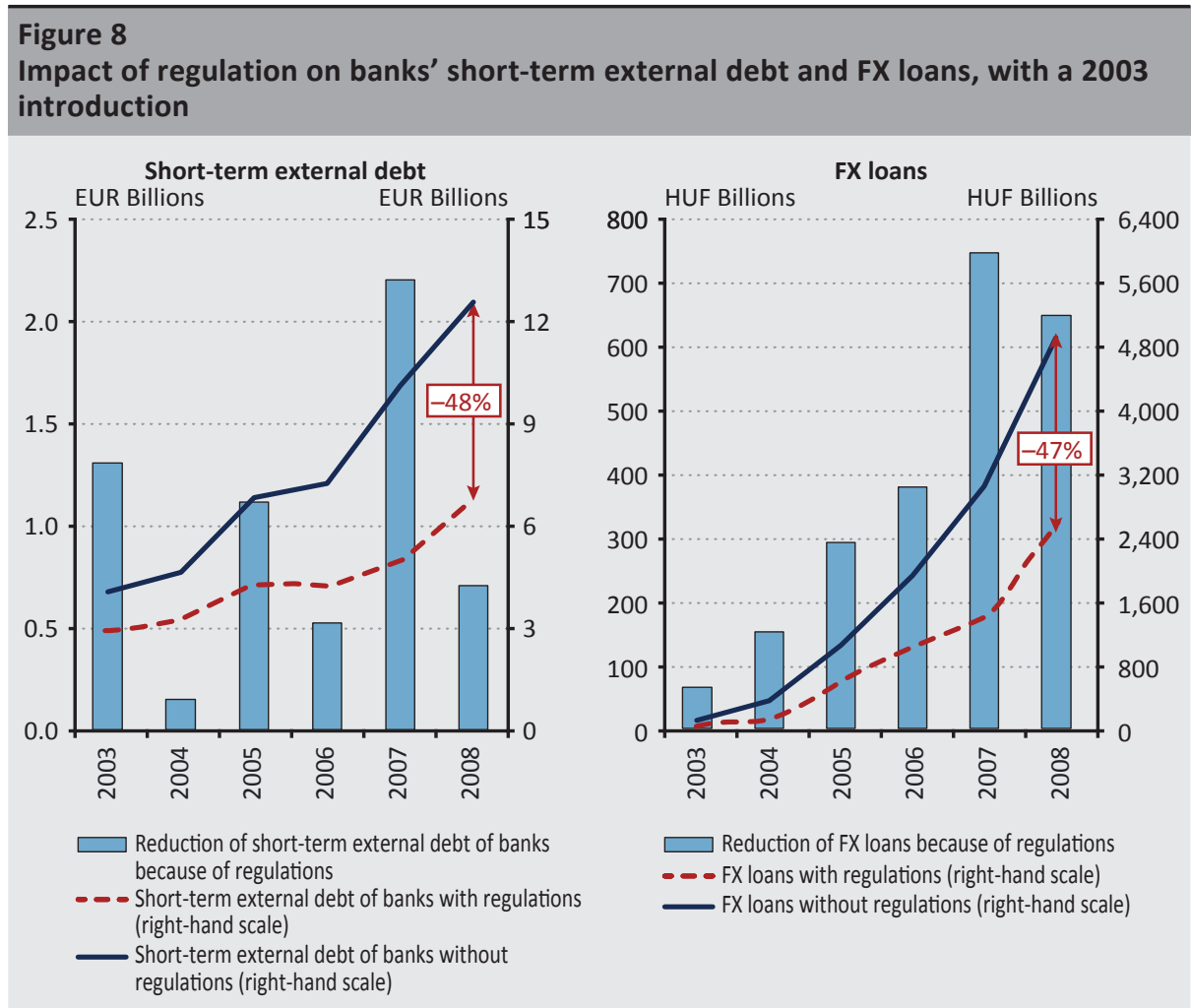

Note: The crowded-out holdings for the years show the amount of holdings that would have had to be adjusted in the given year if the instruments had been introduced in 2003. While the reduction in shortterm external debt is true for both scenarios, FX loan holdings would only have shrunk in the second case.

Source: MNB.

\subsection{Cost estimate in connection with the effects on lending}

In the case of households, costs were approximated with the rise in the debt servicing burden originating from the difference between forint- and FXdenominated borrowing rates, while in the case of banks, the lost debt servicing related to the lost FX loan holdings was used. In the case of the annual adjustment requirement, the annual amount of debt servicing and lost debt servicing was estimated with converting to forint loans to various degrees. The average maturity used in the calculation was 10 years. The formula used to estimate the debt servicing burden was as follows (based on Dynan et al. 2003):

$$
D S_{t}=D_{t} \cdot \frac{i_{t}}{\left(1-\left(1+i_{t}\right)^{-s_{t}}\right)}
$$

where $D S_{t}$ is the debt servicing rate in the period $t, D_{t}$ is the outstanding debt, $i_{t}$ denotes the average annual interest rate and $s_{t}$ stands for the average annual residual maturity of the outstanding debt. 
Large and growing surplus costs would have been incurred by banks mainly because of the potentially lost loans, and by households because of the large spread on forint loans, depending on the size of the FX loan holdings to be reduced and the assumed extent by which forint conversion can be performed (Figure 9).

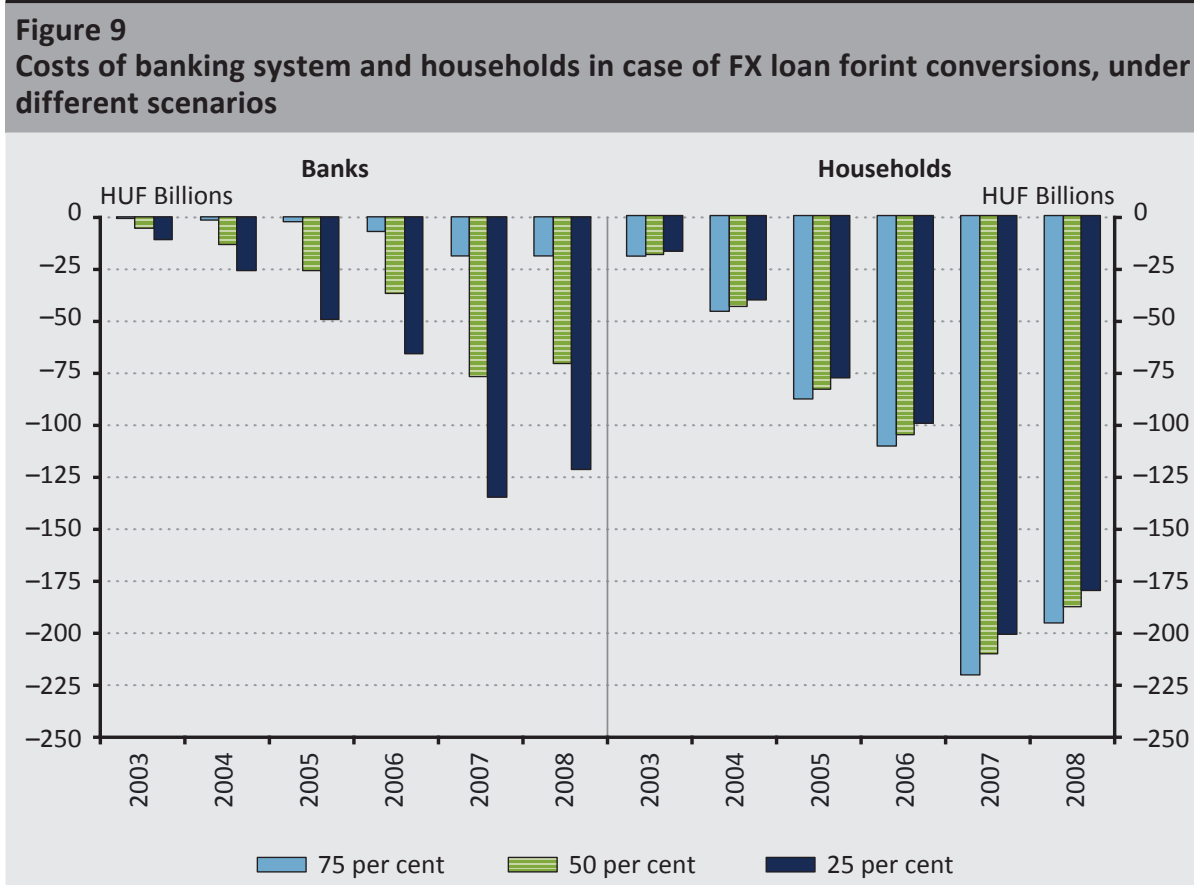

Note: In the case of the annual adjustment requirement, the annual amount of debt servicing (DS) for households and lost debt servicing for banks, with refinancing through various amounts of forint loans, assuming a 10-year average loan maturity. Crowded-out FX loans in the case of the regulation used in the previous year, with proportionate refinancing.

Source: $M N B$

Although the calculation above is admittedly a mere approximation, it has to be noted that these costs would probably have been much lower than the losses realised by households and the banking system in connection with the undertaken exchange rate risk and credit risk, related to the unsustainable banking model, as well as the spillover costs for the national economy, which are well-known to have been high. In the case of the Swiss franc-denominated loans, which comprised the overwhelming majority of household FX loans, on account of the Swiss franc's 60per cent appreciation against the forint between 2008 and November 2014 when the technical forint conversion took place, a revaluation effect amounting to around HUF 1,400 billion may have taken hold in connection with the FX loans shown by our estimate to have been crowded-out by the end of 2008 , amounting to roughly HUF 2,300 billion, with regard to the change in repayment instalments at that time 
and the remaining principal in $2014 .{ }^{16}$ In other words, the early introduction of the regulation would have saved the public this much in losses, which in itself is many times higher than the households' and banks' estimated losses combined. The regulations would have reduced excessive risk-taking by banks and households by internalising risks.

\section{Summary}

Building on the experiences from the 2008 global financial crisis, the MNB devised a comprehensive set of rules, mainly comprising regulations managing currency mismatches and short-term liquidity. To gain a rough picture about the extent by which these reduce the vulnerability of the banking system and thus also the economy, it was examined what impact the pre-crisis implementation of the abovedescribed rules would have had. The backtesting calculation suggests that the liquidity and funding regulations introduced since 2012 would have considerably mitigated the vulnerability of individual banks, the banking sector as a whole and the entire national economy, had they been implemented before the crisis.

With respect to compliance with the regulations, in the case of a liability-side adjustment only, all banks would have improved their ratios, achieving full compliance. However, when the liability-side adjustment is constrained and an asset-side adjustment is permitted, about half of the banks would have been unable to meet all the requirements by relying only on the adjustment methods that were deemed easy to implement and proportionally cost-effective. In all cases, banks would have been forced to adjust the most by the FFAR: in the case of an asset-side adjustment, this would have been the least likely to be met by banks.

The backtesting results show that the short-term interbank external debt would have been substantially lower in all scenarios, which would have translated into considerably lower vulnerability and a smaller international reserve requirement. With an asset-side adjustment, the volume of retail FX loans should have contracted as well through forint conversion, or it would have been unable to build up in the first place, due to the regulatory constraints. These adjustments would have materially improved the stability of the financial system, thereby mitigating the national economy's vulnerability. Finally, the analysis described here also underlines the significance of timing. The costs associated with the adjustment would probably have been much lower than the losses arising from the flawed funding and lending practices. Nevertheless, if the measures had been introduced in 2008, the necessary adjustment would have meant a shock to the banking system. However, this would have been avoidable with an appropriately communicated and timely introduction.

${ }^{16}$ The increased burden caused by the higher interest rates on forint loans was already taken into account among the costs of the regulation. 
This analysis backtested the MNB's current liquidity and funding instruments to show that the applied rules can effectively forestall the financial stress observed in crises, for example in the wake of the present coronavirus pandemic. The rules under review may prevent banks from their over-reliance on short-term, mainly external FX funds, funds from financial corporations or off-balance sheet derivative transactions, which are considered riskier. So based on this analysis, one may argue that the tested instruments would have been able to mitigate the risks associated with excessive FX lending and the high costs incurred by the national economy in connection with this, by internalising the costs of these funding practices paid by households and the banking system.

\section{References}

Acharya, V. - Schaefer, S. (2005): Understanding and managing correlation risk and liquidity risk. International Financial Risk Institute (IFRI) Roundtable, 29-30 September.

Balás, T. - Móré, Cs. (2007): Likviditási kockázat a magyar bankrendszerben (Liquidity risk in the Hungarian banking system). MNB-tanulmányok 69, Magyar Nemzeti Bank, December. https://www.mnb.hu/letoltes/mt-69.pdf

BCBS (2000): Sound practices for managing liquidity in banking organisations. Basel Committee on Banking Supervision, February. https://www.bis.org/publ/bcbsc135.pdf

BCBS (2009): Findings on the interaction of market and credit risk. Working Paper Series No. 16., Basel Committee on Banking Supervision, May. https://www.bis.org/publ/bcbs_wp16. pdf

BCBS (2013): Basel III: The Liquidity Coverage Ratio and liquidity risk monitoring tools. Basel Committee on Banking Supervision, January. https://www.bis.org/publ/bcbs238.pdf

BCBS (2014): Basel III: the net stable funding ratio. Basel Committee on Banking Supervision, October. https://www.bis.org/bcbs/publ/d295.pdf

Baudino, P. - Sturluson, J.T. - Svoronos, J-P. (2020): The banking crisis in Iceland. FSI crisis management series No. 1, Bank for International Settlements. https://www.bis.org/fsi/ fsicms1.pdf

Brunnermeier, M.K. - Pedersen, L.H. (2007): Market Liquidity and Funding Liquidity. NBER Working Paper No. 12939, National Bureau of Economic Research. https://doi. org/10.3386/w12939 
Csávás, Cs. (2015): A devizatartalék-megfelelés értékelésének nemzetközi trendjei (International trends of assessing FX reserves adequacy). Szakmai cikk (Article), Magyar Nemzeti Bank, June. https://www.mnb.hu/letoltes/csavas-csaba-a-devizatartalekmegfeleles-ertekelesenek-nemzetkozi-trendjei.pdf. Downloaded: 10 March 2020.

Dell'Ariccia, G. - Deniz, I. - Lae ven, L.A. (2012): Credit booms and lending standards: Evidence from the subprime mortgage market. Journal of Money, Credit and Banking, 44(2-3): 367-384. https://doi.org/10.1111/j.1538-4616.2011.00491.x

Demyanyk, Y. - Hemert, O. Van (2011): Understanding the Subprime Mortgage Crisis. Review of Financial Studies, 24(6): 1848-1880. https://doi.org/10.1093/rfs/hhp033

Dudley, W. (2014): Welcome remarks. President and Chief Executive Officer of the Federal Reserve Bank of New York, at the workshop on the "Risks of Wholesale Funding", New York City, 13 August.

Dynan, K. - Johnson, K. - Pence, K. (2003): Recent changes to a measure of US household debt service. Federal Reserve Bulletin, 89(10): 417-426.

ECB (2002): Developments in bank's liquidity profile and management. European Central Bank, May. https://www.ecb.europa.eu/pub/pdf/other/banksliquidityprofile02en.pdf

ECB (2010): Financial stability review. European Central Bank, June. https://www.ecb.europa. eu/pub/pdf/fsr/financialstabilityreview201006en.pdf

Fábián, G - Vonnák, B. (eds.) (2014): Átalakulóban a magyar bankrendszer. Vitaindító a magyar bankrendszerre vonatkozó konszenzusos jövőkép kialakításához (Hungarian banking system in transition. A keynote paper for developing a consensus-based vision for the Hungarian). MNB-tanulmányok 112., különszám, Magyar Nemzeti Bank. https:// www.mnb.hu/letoltes/mt112-kulonszam.pdf

Hahm, J.H. - Shin, H.Y. - Shin, K. (2013): Non-Core Bank Liabilities and Financial Vulnerability. Journal of Money, Credit and Banking, 45(s1): 3-36. https://doi.org/10.1111/jmcb.12035

Hartmann, P. (2010): Interaction of market and credit risk. Journal of Banking and Finance. 34(4): 697-702. https://doi.org/10.1016/j.jbankfin.2009.10.013

Huang, R. - Ratnovski, L. (2011): The dark side of bank wholesale funding. Journal of Financial Intermediation, 20(2): 248-263. https://doi.org/10.1016/j.jfi.2010.06.003

Hungarian Financial Supervisory Authority (HFSA) (2013): Risk report 2013/I. Hungarian Financial Supervisory Authority, June. 
Iyer, R. - Peydró, J-L. (2011): Interbank contagion at work: Evidence from a natural experiment. The Review of Financial Studies, 24(4): 1337-1377. https://doi.org/10.1093/ rfs/hhp105

Nagy, M. - Szabó, E.V. (2008): The Sub-prime Crisis and its Impact on the Hungarian Banking Sector. MNB Bulletin, 2008(April): 35-43. https://www.mnb.hu/letoltes/mnb-bull-200804-marton-nagy-viktor-e-szabo-en.pdf

Nagy, M. - Palotai, D. (2014): A devizatartalék óvatosan csökkenthető (FX reserves may be reduced cautiously). Szakmai cikk (Article), Magyar Nemzeti Bank, April. https://www. mnb.hu/letoltes/a-devizatartalek-ovatosan-csokkentheto-2014-04-22.pdf. Downloaded: 6 April 2020.

Nagy M. - Vonnák, B. (2014): Egy jól müködő magyar bankrendszer 10 ismérve (10 features of a well-functioning Hungarian banking sector). Szakmai cikk (Article), Magyar Nemzeti Bank, March. https://www.mnb.hu/sajtoszoba/hirek-2015-juniusig/nagy-marton-vonnakbalazs-egy-jol-mukodo-magyar-bankrendszer-10-ismerve. Downloaded: 10 April 2020.

Páles, J. - Kuti, Zs. - Csávás, Cs. (2010): The role of currency swaps in the domestic banking system and the functioning of the swap market during the crisis. MNB Occasional Papers 90, Magyar Nemzeti Bank. https://www.mnb.hu/letoltes/op-90.pdf

Poghosyan, T. - Čihák, M. (2009): Distress in European Banks: An Analysis Based on a New Data Set. IMF Working Paper No. 09/9. https://doi.org/10.5089/9781451871562.001

Ratnovski, L. - Huang, R. (2009): Why Are Canadian Banks More Resilient? IMF Working Paper No. 09/152. https://doi.org/10.5089/9781451872996.001

Sharma, P. (2004): Speech on liquidity risk. Financial Services Authority, London, October.

Yorulmazer, T. - Goldsmith-Pinkham, P. (2010): Liquidity, Bank Runs, and Bailouts: Spillover Effects During the Northern Rock Episode, Journal of Financial Services Research, 37: 83-98. https://doi.org/10.1007/s10693-009-0079-2 


\section{Annex}

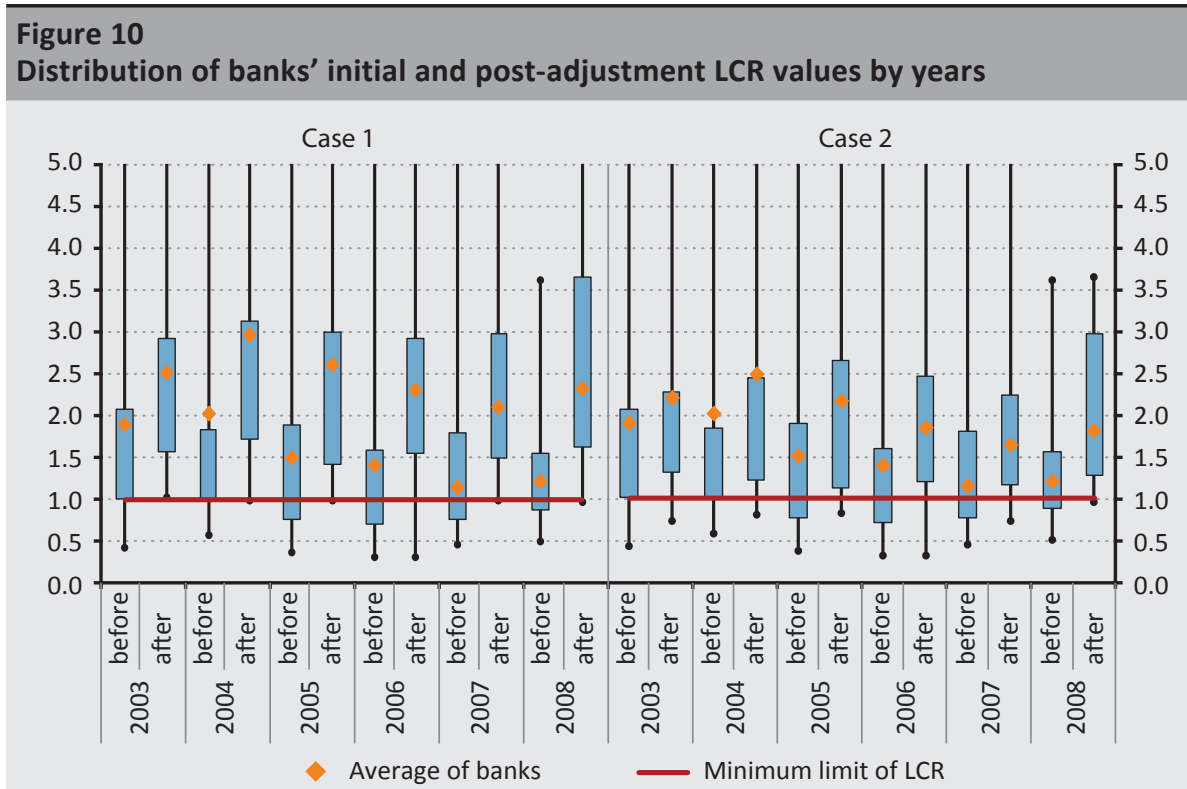

Note: The chart shows the minimum and maximum values, the first and third quartile and the average. Source: $M N B$

\section{Figure 11}

Distribution of banks' initial and post-adjustment FECR values by years

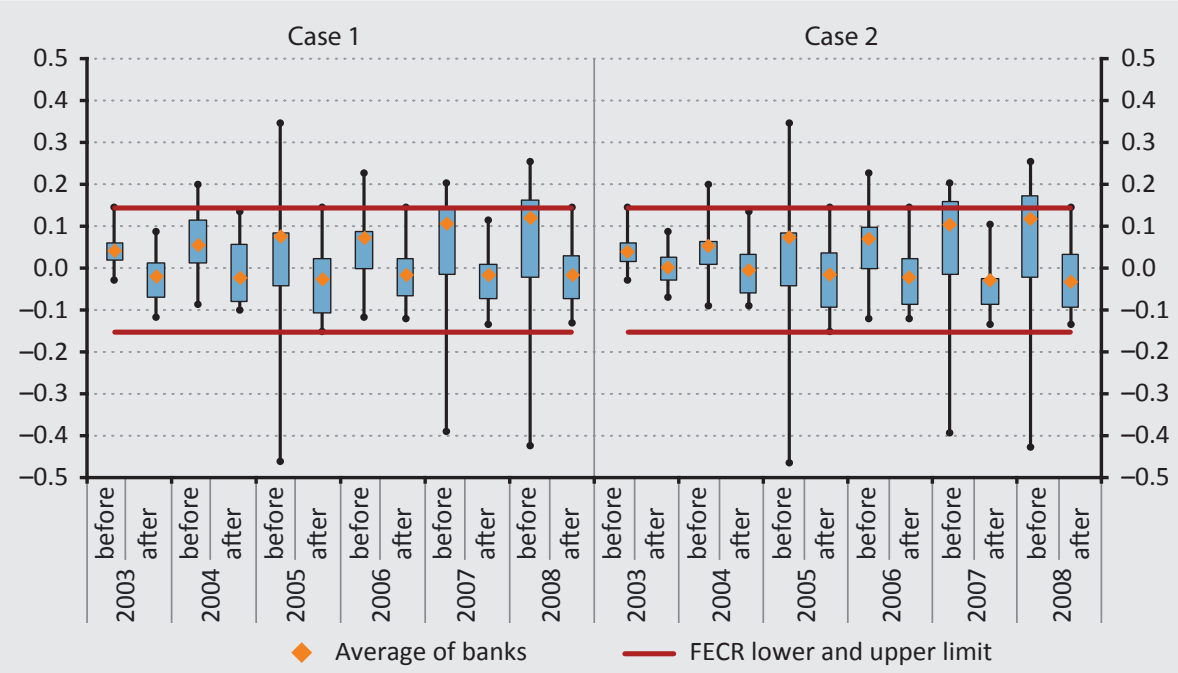

Note: The chart shows the minimum and maximum values, the first and third quartile and the average. Source: MNB 


\section{Figure 12}

Distribution of banks' initial and post-adjustment FFAR values by years

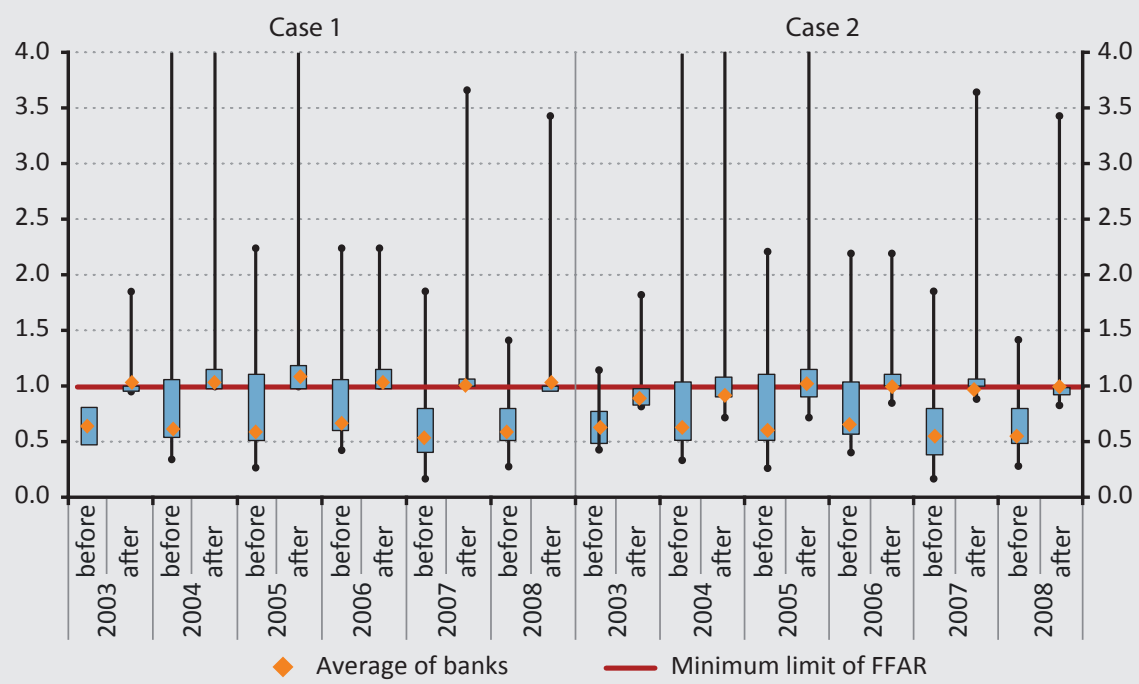

Note: The chart shows the minimum and maximum values, the first and third quartile and the average. Source: $M N B$

\section{Figure 13}

Distribution of banks' initial and post-adjustment IFR values by years

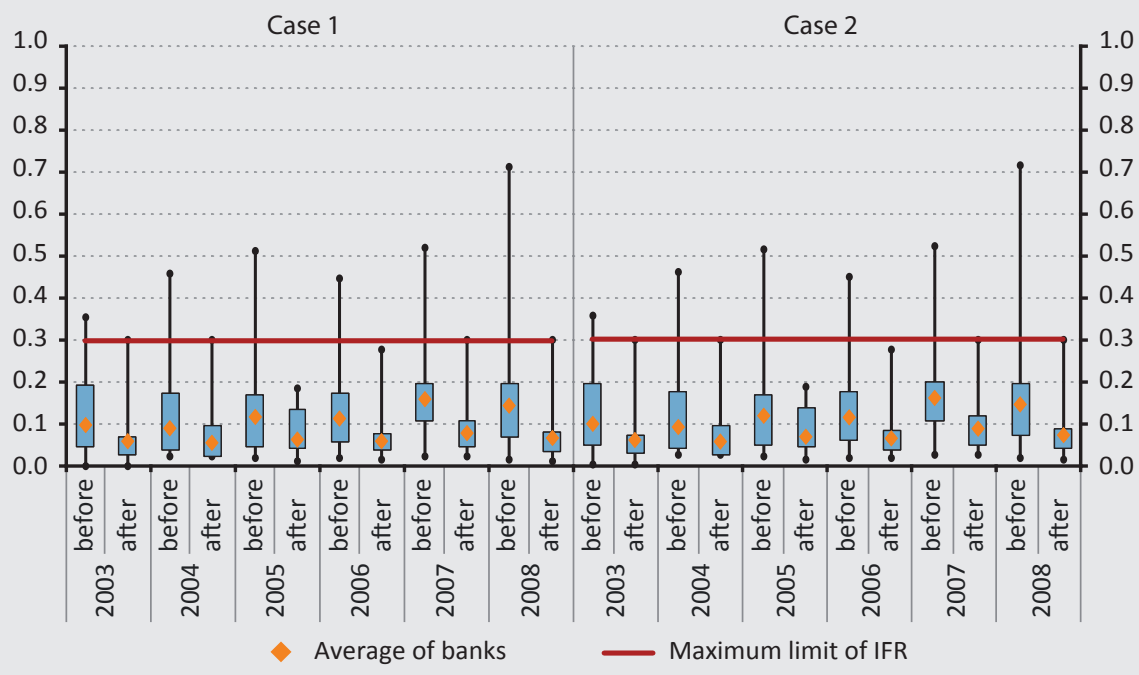

Note: The chart shows the minimum and maximum values, the first and third quartile and the average. Source: MNB 